UNIVERSIDADE DE BRASÍLIA

Centro de Excelência em Turismo

Curso de Especialização em Ecoturismo

\title{
ANÁLISE DO SISTEMA DE SINALIZAÇÃO VISUAL NO JARDIM BOTÂNICO DE BRASÍLIA
}

\author{
Aluna \\ Susana Portilho Troncoso
}

Orientador

Fábio de Jesus

Monografia apresentada ao Centro de Excelência em Turismo da Universidade de Brasília como requisito parcial para a obtenção do

Título de Especialista em Ecoturismo.

Brasília, DF, 26 de maio de 2003. 
Troncoso, Susana Portilho

Análise do Sistema de Sinalização Visual no Jardim

Botânico de Brasília/ Susana Troncoso. Brasília, 2003.

Monografia Ecoturismo - Universidade de Brasília. Centro

de Excelência em Turismo.

Analysis of the Visual Signing System of the Brasilia

Botanical Garden

1. Turismo 2. Ecoturismo 3. Sinalização Gráfica 


\section{AGRADECIMENTOS}

Agradeço primeiro a Deus e a minha tia Jane pelo curso. Agradeço também aos professores Fábio de Jesus e Danilo Barbosa e ao meu pai Carlos Troncoso pela orientação do trabalho. 


\section{RESUMO}

O presente estudo tem por objetivo avaliar o Sistema de Sinalização Gráfica atual da área de visitação e trilhas no Jardim Botânico de Brasília. Após comparação com sugestões contidas nas obras dos especialistas no assunto, apresenta recomendações para a elaboração de projeto de sinalização naquela mesma área, que são as trilhas e a área de visitação. 


\section{Abstract}

The present stdudy has as objective, analysing the actual Graphic Sign System at the visiting and trail areas of the Brasília Botanical Garden. It compares it to suggestions found in the literary work of specialists in this subject and presents recomendations for a sign project at the same places, which are, trails and visiting areas. 


\section{Sumário}

Seção

Página

Capítulo 1 - Introdução

01

Capítulo 2 -Revisão da Literatura

05

Capítulo 3 - Procedimentos Metodológicos

Capítulo 4 - Resultados

Capítulo 5 - Discussão

Considerações Finais

56

Referências Bibliográficas

57

Glossário

58

Lista de figuras

23

Tabela 01

44

Tabela 02

54 


\section{CAPÍTULO 1 - INTRODUÇÃO}

Pinturas e esculturas em cavernas na pré-história ilustravam acontecimentos da época: as tribos primitivas usavam sinais de fumaça e habitantes das florestas fazem incisões em árvores para se orientarem na floresta.Antes de 3000 a.C., os egípcios se utilizavam de linguagem que usava figuras chamadas hieróglifos (Universal, 1988).

Os agricultores interpretam as mudanças no clima para decidir qual é o melhor momento para plantio. Adornos característicos de cada povo permitem a distinção entre homens e mulheres, religiões, classes sociais e partidos políticos e os antigos navegadores puderam chegar em continentes diferentes por orientação baseada nos astros (Universal, 1988).

Não se sabe quando, exatamente, o homem aprendeu a falar nem quem foi o primeiro homem a falar, mas cerca de 300 a.C. os indianos inventaram os números. No séc. Il tinta e papel começaram a ser usados e os monges da Idade Média escreveram livros em pergaminhos, copiando letra por letra os manuscritos (Universal, 1988).

A fala, os manuscritos e os sinais de fumaça são formas de comunicação. A comunicação está presente ao longo de toda nossa vida. Alguém ou o despertador nos avisa que é hora de acordar, o painel do carro mostra se tudo está em ordem para dirigi-lo, o rádio nos informa sobre as notícias do dia e o telefone quando toca nos avisa que alguém quer falar conosco. Para que estas mensagens sejam transmitidas, é preciso um canal de comunicação que pode ser oral, sonoro ou visual, quando um professor ministra uma aula, quando sorrimos ou quando lemos um livro.

Todas estas são formas de expressão de idéias e pensamentos de que o ser humano se utiliza para estabelecer comunicação e interagir com o ambiente que o cerca e que se traduzem em linguagens.

O presente estudo trata da linguagem visual que é a sinalização e utiliza os símbolos, que são figuras e desenhos em geral, bem como os textos, que são a linguagem escrita.

A linguagem visual gráfica para fins dessa monografia será denominada Sinalização. Este instrumento, a sinalização, auxilia nas tomadas de decisões das pessoas em relação aos trajetos até escolas, teatros, endereços residenciais, observação de algum monumento, identificação de edifícios e os procedimentos a serem adotados fora e dentro destes locais, sendo estas pessoas pedestres ou condutores de qualquer meio de transporte.

A sinalização é importante instrumento na organização e ocupação dos espaços utilizáveis, quando há correta orientação (Barbosa \& Troncoso, 1997).

Toda esta orientação pode ser feita por meio de mensagens, que devem ser claras e objetivas, sem que haja dúvidas em seu significado, caso contrário pode haver confusão na sua compreensão, impedindo que decisões sejam tomadas de forma correta e desejável. 
Dentre aqueles locais e ambientes onde a sinalização pode ser utilizada, destacam-se, neste estudo, as áreas naturais freqüentadas para a prática do ecoturismo.

Os praticantes do ecoturismo procuram cada vez mais fugir da rotina e estresse diários dos centros urbanos e querem conhecer lugares novos, novas culturas, em busca de descanso e muitas vezes oportunidades de aventura e liberdade.

Estas pessoas que querem maior contato com a natureza precisam observar alguns aspectos para que as atividades de turismo sejam compatíveis com sua segurança pessoal e a conservação das áreas onde são praticadas.

Os visitantes devem ser, sempre que possível, instruídos para que a consciência ambiental seja cada vez mais consolidada. Devem também conservar os patrimônios natural e cultural, permitir o desenvolvimento econômico da região e promover o bem-estar das populações tradicionais locais (MMA, 2002).

Assim, a partir do momento em que estes aspectos forem seguidos e equilibrados entre si, teremos um ecoturismo responsável.

O ecoturismo é uma das modalidades de turismo que mais crescem em todo o mundo. Isto significa que muitos setores da sociedade ligados às atividades de ecoturismo estão se mobilizando, tendo em vista que mais pessoas estão viajando e visitando áreas naturais, portanto, a educação e sensibilização dos visitantes devem promover a conservação destas áreas, principalmente espaços mais sensíveis (MMA, 2002).

A sinalização deve ser um instrumento utilizado pelos responsáveis pelo manejo das áreas naturais que recebem visitação para que estes promovam a orientação do uso adequado dos espaços e informem as normas específicas para isso.

Organizar e informar, através da elaboração eficiente do planejamento do sistema de comunicação visual para o uso adequado dos espaços é extremamente importante, pois essas áreas naturais ainda preservam grande parte das relações entre fauna e flora.

A utilização do sistema de sinalização possibilita que a atividade de visitação seja realizada, cumprindo assim, alguns dos objetivos de criação destas áreas, através da proteção dos recursos naturais e culturais e possibilitando uma maior aproximação e interação dos visitantes com esses recursos.

O cuidado na elaboração e implantação do sistema de sinalização é importante porque a introdução de elementos que não estavam presentes no local, originalmente, significa uma interferência. As indicações visuais devem ser feitas para que chamem suficientemente a atenção dos visitantes, despertando nestes o interesse pelo seu conteúdo, mas discretas o bastante para não competirem com os atrativos naturais. 
Por estes motivos, é importante que os responsáveis pelas áreas de preservação se assegurem de que os sistemas de comunicação visual utilizados em suas unidades estão seguindo certos padrões adotados pelos especialistas da área.

Como já mencionado, o objetivo geral da sinalização em área natural é o auxílio no processo da manutenção da área de preservação, contribuindo para sua sustentabilidade. Isso se dá pelo ordenamento e conteúdo das informações transmitidas.

A presente monografia tem como objetivo específico levantar e estudar a sinalização existente na área de visitação no Jardim Botânico de Brasília (JBB).

No presente estudo, foi realizada a comparação do sistema de sinalização implantado no JBB, com os marcos teórico e prático de estudos e trabalhos realizados em outras áreas naturais e urbanas, levando-se em consideração suas particularidades.

Através deste procedimento buscou-se a constatação de que a sinalização existente no JBB está ou não de acordo com recomendações dos especialistas, sendo que para tal, o método utilizado foi a observação e comparação.

Este estudo foi realizado na área de visitação do JBB, com vistas à análise do sistema de sinalização implantado e pelo fato do mesmo ter sido realizado sem a elaboração de um projeto específico.

Para tal, foram analisados os aspectos técnicos relacionados à cores, formas, tamanhos, tipos de letras e disposição dos elementos. seguir:

O presente estudo é composto por quatro capítulos apresentados a

Capítulo 1 - Introdução - traz as primeiras idéias sobre a sinalização visual e sua importância para as pessoas, tanto de forma geral como para os usuários e organizadores de espaços naturais.

Capítulo 2 - Revisão da Literatura - contém informações técnicas sobre sinalização segundo autores especialistas na área. Em suas obras, estes autores apresentam os procedimentos de planejamento adotados para um sistema de sinalização, como esta é importante para organização dos espaços e quais suas recomendações em relação à elaboração dos elementos gráficos.

Capítulo. 3 - Procedimentos Metodológicos - traz a metodologia utilizada na pesquisa, que foi baseada na observação e comparação, quando foi feita e como foram seus procedimentos.

Capítulo 4 - Resultados da Pesquisa - apresenta os resultados da pesquisa, o que foi levantado, quantos elementos foram contabilizados, quantos modelos existem na área, onde se encontram e seu enquadramento nos propósitos conceituais. 
Capítulo 5 - Discussão dos Resultados da Pesquisa - neste capítulo são feitas as comparações entre a sinalização encontrada no JBB e a literatura citada e são apresentadas as propostas de modelos de acordo com a literatura utilizada. 


\section{CAPÍTULO 2 -REVISÃO DA LITERATURA}

No Brasil existem ainda poucos manuais ou obras que forneçam bases técnicas para o planejamento de sinalização em áreas naturais.

Os autores Barbosa \& Troncoso (1997), ao produzirem a Orientação para Sinalização Visual de Unidades de Conservação Federais, procuram oferecer um roteiro para auxiliar os administradores das Unidades de Conservação (UC) na elaboração do sistema de sinalização em áreas protegidas e fazem as seguintes recomendações:

Por se tratar de áreas protegidas, onde o objetivo é a conservação da natureza, a qual o Sistema Nacional de Unidades de Conservação da Natureza (SNUC) define como "o manejo do uso humano, compreendendo a preservação, a manutenção, a utilização sustentável, a restauração e recuperação do ambiente natural, para que possam produzir o maior benefício, em bases sustentáveis, às atuais gerações, mantendo seu potencial de satisfazer as necessidades e aspirações das gerações futuras, e garantindo a sobrevivência dos seres vivos em geral" (Brasil, 2000).

Conforme os autores acima citados, a sinalização deve contribuir para a conservação da natureza das áreas protegidas, por meio de indicações de acesso, boa circulação de pedestres e motoristas, indicação de serviços, necessidade do uso de algum equipamento de segurança e normas de funcionamento.

Para que estes aspectos sejam bem desenvolvidos, deve-se fazer um estudo do espaço físico e recursos naturais da área a ser contemplada pelo projeto e ter conhecimento do Plano de Manejo, que estabelece o tipo de uso que os espaços podem ter.

Para o estudo do espaço físico, é importante a obtenção de mapas da área trabalhada e, se for o caso, projetos arquitetônicos de edificações a serem sinalizados.

Ao desenvolver o projeto, deve-se prever a veiculação de mensagens de possíveis patrocinadores, permitindo que sua marca seja inserida em local adequado do elemento.

A implantação da sinalização permite aos usuários e administração algumas comodidades como: estar à disposição do visitante a qualquer hora, se houver necessidade pode ser trocada e não exige a presença de um guia. Por outro lado, não fornece feedback ao visitante e se for mal planejada pode competir com os atrativos. O que significa não interferir na percepção e leitura da mensagem principal.

Para que os sinais não concorram com os atrativos, devem ser implantados somente quando sua presença for indispensável. Em outras palavras, somente quando sua ausência puder comprometer o ordenamento do uso do espaço ou a segurança do visitante. 
Além de indispensáveis, os sinais devem estar em pontos estratégicos, evitando sua colocação em locais que ofereçam risco ao visitante para a obtenção da informação.

Os sinais devem ser vistos sem que o usuário tenha de se abaixar, procurá-los ou que venham a ser encobertos por vegetação. Em casos de duplo sentido em uma direção, disponibilizar as informações para os dois lados proporcionando assim, a comodidade necessária para a observação.

No planejamento do sistema de sinalização, não devem ser esquecidos os elementos que são externos à área escolhida. Deve-se solicitar ao departamento de trânsito responsável pela rodovia que dá acesso à unidade que se implante elementos indicando a distância, aproximação e identificação e do local.

Os locais estratégicos começam na área externa à unidade. A chamada pré-sinalização é a que se coloca de 50 a $75 \mathrm{~m}$ antes da interseção viária para que o condutor tenha tempo hábil de olhar, assimilar a mensagem e tomar a decisão de entrar, sendo que se admite o mínimo de $60 \mathrm{~m}$ para as vias de 60 $\mathrm{km} / \mathrm{h}$.

Quando se fala de sinais ou símbolos que compõem elementos da sinalização, deve-se evitar a repetição de mensagens para que estas não se tornem desinteressantes.

$\mathrm{Na}$ elaboração do projeto a ser implantado, algumas normas técnicas são recomendadas para que haja o máximo de uniformidade.

No processo de uniformização dos sinais para o estabelecimento de uma identidade visual, recomenda-se neste trabalho a utilização de um alfabeto-padrão para todas as situações, a não ser quando se tratar de alguma legislação específica como o Código Nacional de Trânsito. O alfabeto pode ser na versão Negrito para títulos e mensagens principais, Demi para mensagens complementares e Demi itálico quando em outro idioma. As mensagens devem ser grafadas em caixa alta. É recomendado o uso das fontes Optima ou Zapf Humanist 601, cujos exemplos podem ser vistos a seguir.

\section{ABCDEFGHIJKLMabcdefghij012345678}

Zapf Humanist 601 Negrito

\section{ABCDEFGHIJKLMabcdefghij012345678}

Zapf Humanist 601 Demi

\section{ABCDEFGHIJKLMabcdefghij012345678}

\section{Zapf Humanist 601 Demi itálico}

Outro componente que deve ser padronizado é a cor, ou código cromático, que deve ser especificado com base nas referências do sistema internacional PANTONE. 


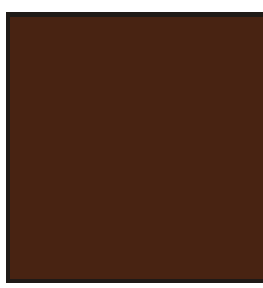

MARROM

Pantone: 4625c

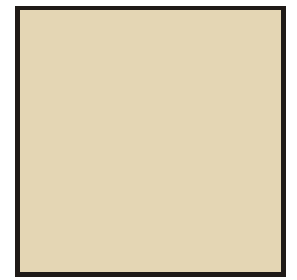

AREIA

Pantone: 468c

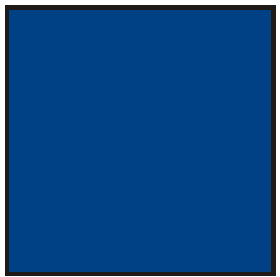

AZUL

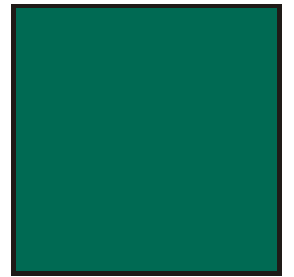

VERDE

Pantone:294c

Pantone: 342 C

$\mathrm{Na}$ elaboração do projeto, são utilizados ainda elementos que auxiliam na compreensão da mensagem por se tratarem de símbolos, como, por exemplo, os signos direcionais, mais conhecidos como "setas". São sinais que indicam a direção que se deve seguir. Para sua utilização, existem critérios de ordenamento estabelecidos para uma padronização que são:

1. Em frente:

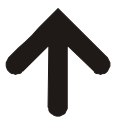

4. À esquerda:

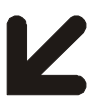

7. À direita:

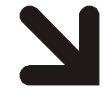

2. À esquerda:

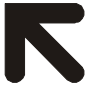

5. À direita:

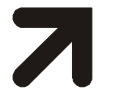

8. Abaixo:

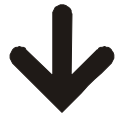

3. À esquerda:

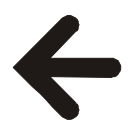

6. À direita:

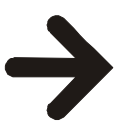

No momento da fabricação dos elementos, a escolha do material é feita de acordo com a facilidade de obtenção no local, resistência às condições climáticas e ao vandalismo, durabilidade, custo e estética. Essa escolha é feita pelo profissional responsável pelo projeto e as opções mais usadas são:

- $\quad$ Madeira,

- Ferro,

- Aço,

- $\quad$ Alumínio, 
- $\quad$ Concreto,

- Pedra,

- $\quad$ Fibra de vidro,

- Vidro,

- $\quad$ Acrílico

O acabamento dos elementos será de acordo com o material escolhido e a aplicação da mensagem deve ser feita com película refletiva sempre que necessária, de modo a permitir sua leitura à noite pelo usuário motorizado.

Os profissionais responsáveis deverão realizar visitas à unidade para reconhecimento, verificar se já existe algum projeto anterior, conhecer mapas da área, definir suas necessidades de sinalização e identificar então os fluxos de circulação de veículos e pedrestes. Nestas visitas devem ser previstas reuniões com o corpo técnico da unidade. A partir daí, são feitos estudos preliminares para se definir a técnica construtiva a ser empregada e viabilizar sua execução.

Maiores detalhes a respeito das indicações técnicas deste manual podem ser observados ao longo do capítulo 04 - Discussão dos Resultados da Pesquisa.

Follis \& Hammer (1979) ressaltam que quando se trata de áreas naturais, é fundamental observar se a sinalização está sendo útil sem causar alguma poluição visual. Deve-se ter o cuidado para que ela não esteja competindo com os outros elementos presentes como as paisagens ou atrativos. Suas propostas são apresentadas e comentadas a seguir.

Os visitantes destas áreas naturais têm grande necessidade de informações para que sua visita seja o mais proveitosa possível. Se estiver bem planejada, a sinalização pode trazer tais informações com eficiência e se estiver disposta como sistema gráfico todos seus elementos devem se completar, deixando de ser mensagens isoladas.

Segundo esses autores, os sinais também devem servir para a identificação das áreas ou serviços, indicar a direção que se deve tomar ou mesmo informar sobre o atrativo ou regulamento do local.

Os usuários têm respostas diferentes aos sinais dependendo de fatores individualizados, que são físicos e psicológicos e que proporcionam as percepções em relação às cores, formas e até capacidade de memorização.

A partir destes fatores deve haver, num sistema, elementos apropriados para pedestres e para motoristas e que nem sempre servirão para ambos. A legibilidade para os motoristas depende da velocidade em que estes se encontram e da distância necessária para reconhecimento da mensagem. 
Sabe-se que a capacidade de leitura das pessoas pode variar entre 125 e 500 ou 600 palavras por minuto dependendo da idade e forma de educação, como média se utiliza a quantia de 250 palavras por minuto. Assim, estimou-se que os sinais não devem conter mais do que 6 itens em seu texto.

Além de saber se o sinal serve para pedestres e motoristas, é importante também se observar se a visualização está sendo obstruída por árvores ou arbustos no caso de áreas naturais e se está no campo normal de visão das pessoas. Este campo é estimado entre $60^{\circ}$ horizontalmente e $30^{\circ}$ verticalmente. A altura média dos olhos de uma pessoa em pé é de aproximadamente $1,70 \mathrm{~m}$, de uma pessoa sentada é de $1,30 \mathrm{~m}$ e quando está dentro de um veículo que não seja camioneta ou caminhão, é de 1,40 m.

A luminosidade e iluminação são aspectos a serem levados em consideração para o planejamento, pois podem alterar o aspecto e visibilidade da sinalização. Como estaremos tratando de luz natural e observação diurna, não serão utilizados quaisquer artifícios para mudança de cores, formas ou textura.

Outra característica bastante comum às pessoas é que a maior parte delas responde melhor à mensagens que são transmitidas verbalmente ou por meio de letras. Quando os símbolos são usados sozinhos podem ter dupla interpretação, recomendando-se, portanto, o uso deles com o texto.

As letras do texto, todavia, não devem estar dispostas muito espaçadamente nem muito próximas umas das outras. Sabe-se que a cada 15 $\mathrm{m}$ de distância entre o leitor e a mensagem, devem ser acrescentados $2,5 \mathrm{~cm}$ no tamanho da letra e uma fonte bastante aceita é a Helvetica, exemplificada abaixo.

\section{ABCDEFGHIJKLMahcdefghij012345678}

Helvetica Demi

\section{ABCDEFEHIJIILMabcdefghijO12345678}

Helvetica Itálico

As cores são outro fator importante e as mais percebidas pela maioria das pessoas são o vermelho, amarelo, azul, verde, laranja e marrom. As outras cores são normalmente identificadas em segundo plano e o uso de algumas já foi regulamentada, como por exemplo, no Código de Trânsito.

As cores a serem usadas não devem ser escolhidas somente porque combinam entre si ou porque foram utilizadas anteriormente: elas devem se relacionar também com o meio em questão e com o material que servirá para a fabricação dos elementos.

A repetição do material ao longo de uma área garante a unidade desejável e padronização visual do sistema visual. Sua escolha vai depender do ambiente e condições climáticas, principalmente se forem lugares abertos. As condições de tempo são, na verdade, fatores limitantes para o uso de alguns materiais, que no caso podem ser: 
- Metal

- Madeira

- Acrílico

- Alumínio

- Pedras

- Concreto

- Fibra de vidro

Algumas destas matérias primas são caras, porém não é somente o custo inicial de fabricação e instalação que devem ser levados em consideração. Também a resistência, o tamanho da peça, a facilidade de manipulação de alguma forma especial e, principalmente, os custos da manutenção devem ser observados. Quando a manutenção é fácil e a peça durável, uma sinalização inicialmente cara pode significar redução de despesas a médio e longo prazos. Se somente o custo for determinante para a escolha, pode se tornar um transtorno posteriormente por causa da ação do tempo, do clima e do vandalismo.

Segundo Moore (1993), em seus estudos sobre sinalização interpretativa, quando forem utilizados painéis ou letreiros de sinalização externa é importante se observar se há a necessidade de alguma estrutura protetora, algum refúgio que possa abrigar o elemento da ação do tempo, clima ou mesmo vandalismo.

Além dos abrigos, para a proteção dos elementos, a escolha dos locais onde serão instalados também é importante. Em locais onde existe um roteiro a ser percorrido, os pontos de parada ou descanso são lugares bastante indicados para a sinalização, pois o visitante dispõe de mais tempo no local. (Moore 1993))

Os elementos da sinalização devem estar em posições de fácil localização pelo visitante, em espaços que não representem perigo ou não necessitem de deslocamentos desconfortáveis e não deixem dúvidas para o visitante: o visitante tem que ser capaz de olhar tanto o atrativo como a mensagem sem ter que mudar de posição. É importante que a mensagem seja de fácil alcance visual, sem esforço para sua observação. O autor estima que isso esteja entre 50 e $60 \mathrm{~cm}$ de altura, mas já foi observado na prática que o mais confortável fica acima disso, entre 1 e 1,20m. Nos casos de identificação de espécies vegetais o elemento ficaria na altura sugerida e com dimensões menores que o restante (Moore 1993).

Moore (1993) ainda recomenda que se deve priorizar os pontos onde a visitação é maior, mas não se deve esquecer dos menos freqüentados porque sempre pode haver alguém ali precisando de uma informação ou advertência. 
Se para estas informações for utilizada a mensagem com símbolos e texto ou somente texto, é muito importante que se use caixa alta e baixa, ou seja, letras maiúsculas e minúsculas, pois se sabe que o uso de somente uma delas, cria monotonia, a atenção é menor e o tempo de leitura maior (Moore 1993).

O vandalismo e a ação do tempo são fatores que exigem a manutenção constante do material. Este deve ser facilmente limpo ou de fácil substituição. Em especial nos casos de vandalismo, manter o local limpo parece inibir um pouco a ação depredatória (Moore 1993).

Algumas mensagens podem ser temporárias, como o desvio de alguma trilha em recuperação ou obra e deve-se ter em mente algum modelo para estes casos (Moore 1993).

Os materiais utilizados na confecção podem ser da região, como pedras, madeira ou metal, que ajudam na harmonia com o ambiente, devendo-se tomar muito cuidado com legislações vigentes, regulamentações ou restrições a alguma matéria prima, para que não haja exploração irresponsável dos recursos naturais (Moore 1993)

O Departamento de Interior dos Estados Unidos, através do Serviço Nacional de Parques, quando planeja um sistema de sinalização gráfica que visa atender tanto pedestres quanto motoristas, considera importante observar como estarão dispostos os elementos, tamanhos, cores e formas a serem estabelecidos de acordo com a velocidade média das vias e as distância entre o visitante e as mensagens (Moore 1993).

Depois deste planejamento, é interessante que se crie um código para identificação de todos os elementos da sinalização para constar em inventário. Isso ajudará no controle das placas por parte da administração, de quantas existem, se alguma foi retirada por avarias ou mesmo se foram incluídos elementos novos (Moore 1993).

Farina (1982) mostra estudos que analisam as preferências das pessoas em relação às cores e revelam que suas reações não são em resposta somente à elas, mas também aos contextos em que se apresentam. As pessoas guardam na memória, situações e seus significados relacionados às cores, mas muitas vezes estes significados vêm da cultura ou meio em que estão inseridos.

Diz também que quando se fala em cores, não são as combinações que devem ser cuidadosamente escolhidas, alguns contrastes também são mais eficientes e se fixam melhor que outros. Por exemplo, o azul é uma cor que se fixa quando usado em letras e formas, mas não fica bem quando usado como fundo de elementos. O amarelo não deve ser utilizado em contornos e cores que têm um bom contraste entre si são o verde e vermelho e o verde e laranja (Farina 1982).

Na publicidade, seja com cores, palavras ou formas, o objetivo é se alcançar o indivíduo por meio de mensagem para provocar-lhe uma ação. A capacidade de fixar a atenção e conseguir do usuário a assimilação da 
mensagem está muito relacionada à simplicidade desta, à sua precisão em ser transmitida (Farina 1982).

Os significados ou sensações que as cores proporcionam não estão ligados só à cultura, mas também têm influências fisiológicas sobre os seres vivos. O azul, por exemplo, transmite clareza, calma, ternura e quando é o marinho, sobriedade. O bege é atraente e é bem usado em ambientes de trabalho. O verde representa paz, tranqüilidade, segurança e, obviamente, lembra as formas de vegetação. O laranja provoca alegria, felicidade e vida já o marrom não costuma provocar nenhuma reação (Farina 1982).

Algumas combinações são agradáveis apesar de serem contrastantes, como, por exemplo, vermelho/azul, azul/amarelo, vermelho/amarelo, amarelo/preto, verde/azul e azul/branco (Farina 1982).

Sims (1991) lembra que segundo a US Society of Enviromental Graphic Designs (SEGD) o design dos ambientes cumpre funções básicas: ajudar os usuários a se desenvolverem no espaço, identificar, dirigir e informar algo para realçar visualmente o entorno e também proteger a segurança do público.

Em seus trabalhos, Sims (1991) ressalta os propósitos de Jock Kinner, desenhista inglês de sinalização, que em seu livro Words and Building, apresenta a idéia de que "Através de sua interpretação, a sinalização comunica aquilo que de outra forma seria impossível de captar".

Ainda segundo Sims, a sinalização deve permitir, em curto espaço de tempo, que o usuário tome decisões em um primeiro momento, depois coloque em prática sua decisão, que seria a execução de um comportamento e por fim, ter a percepção e tomar conhecimento do ambiente que o envolve.

Para trabalhar didaticamente com a sinalização e de acordo com suas funções, os tipos principais são:

- $\quad$ Orientadoras: situam o usuário em um ambiente e permite que ele se localize: são mapas e planos.

- Informativas: dizem o que se deve e se pode fazer, como horários de funcionamento e acontecimentos.

- Direcionais: indica como deve ser a circulação no local e a utilização com eficácia e segurança das instalações.

- Identificadoras: permite o reconhecimento do local, serviço ou estrutura e edifícios.

- Reguladoras: normas para proibição de alguma atividade, de segurança e procedimentos em casos de emergência.

- Ornamentais: realçam o aspecto ou efeito geral de um ambiente. São bandeiras ou placas comemorativas. 
Em todos estes tipos de sinalização, podem ser usados textos com letras variadas. Existem mais de 10.000 estilos de alfabeto sendo que estes podem ter versões itálicas ou romanas diferenciando no tamanho, espessura e estilo decorativo como, por exemplo, sombreado.

Não existem letras boas ou ruins e sim melhores ou piores segundo seu uso. As mais usadas e clássicas, são a serifada Times e a sem serifa Frutiger ou Helvetica. Não devem ser muito finas para continuarem visíveis a uma certa distância e nem muito espessas para não darem a impressão de que estão amontoadas. Enfim, umas são mais legíveis que outras, umas são mais adequadas para o tipo de impressão a que será submetida ou para os diferentes tipos de material.

Legibilidade significa que os caracteres podem ser vistos e compreendidos. A legibilidade pode ser comprometida por fatores externos como sombras sobre o elemento e mesmo luz direta incidindo sobre ele causando reflexos ou sombras. Muitas vezes as pessoas se acostumam com o aspecto do elemento e o que antes era ilegível passa a ser reconhecido com familiaridade (Sims 1991).

Os textos devem ser claros, consistentes, o mais curtos possível e sem duplicidade em sua interpretação. Devem ser em tom cortês, com frases amistosas e positivas, pois desta forma ajudam a induzir o usuário a uma resposta positiva em lugar de negativa (Sims 1991).

A cor utilizada no elemento pode criar uma atmosfera com mais alegria ou tristeza. O branco e o preto devem ser considerados como cores e não a simples presença ou ausência de todas e o material escolhido deve estar relacionado a elas (Sims 1991).

Os processos ou técnicas de utilização do material podem ser:

- $\quad$ Serigrafia: usa-se um filme, que pode ser um fotolito, para a impressão com o desenho desejado por cima do material a ser trabalhado e uma tela de fibra sintética fixada em uma moldura com alguns espaços tampados de acordo com o desenho.

- Jato de areia: usa-se uma tela com papel aderente, goma ou plástico que endureça para absorver os grãos de areia do jato. A imagem se produz pela abrasão da área não protegida. Exige mão de obra especializada e pode ser usada em plástico, madeira, metal, vidro, pedras e outros.

- Fundição: quando se molda partes do material colocando-as juntas, usando metais, plástico ou vidro.

- $\quad$ Extrusão: quando se modela material usando moldes.

- Gravação: permite gravar à mão ou com uma máquina à laser.

Para a escolha dos materiais, deve-se pensar em seu uso, durabilidade, custo, resistência e aspecto estético, podendo ser: 
- $\quad$ Plástico: muito utilizado, de fácil fabricação e suporta bem os agentes atmosféricos. Está sujeito a alterações de suas dimensões com a variação de temperaturas, podendo rachar ou deformar

- Acrílicos: são tipos de plástico transparente ou colorido, com textura brilhante ou opaca. São resistentes aos efeitos do ambiente e perdem pouca cor pela ação do sol. Têm pouca resistência a impactos mecânicos e pouca dureza superficial, mas podem ser tratados com revestimentos resistentes. São altamente inflamáveis, mas para isso também podem ser tratados.

\section{do fogo. \\ - Policarbonato: material muito duro e resistente a impactos e ação}

- $\quad$ Fibra de vidro: usado para revestimento de outro material como madeira e plástico sendo muito durável e resistente.

- $\quad$ Aço: de fácil fabricação, tratado quase sempre com níquel e molibdênio para ter melhorada sua resistência à corrosão, o que o torna mais caro; admite soldas.

- $\quad$ Alumínio: muito leve, resistente à corrosão química, durável, não combustível e não tóxico. Pode ser aliado a outros metais para se obter outras características e propriedades. Fácil maneabilidade.

- $\quad$ Madeira: largamente utilizada, facilmente trabalhada permitindo criar formas pouco habituais. Seu aspecto final depende da madeira escolhida, podendo ser dura ou mole. As duras são geralmente árvores de clima quente $\mathrm{e}$ tropical como aroeira e são mais duráveis e melhor usadas na sinalização. As consideradas moles são as de clima mais frio ou temperado, mais adequadas para uso em interiores: são as coníferas de forma geral - pinheiros, abetos, cedros, sequóias e ciprestes. A madeira deve ser tratada para se evitar ataques de insetos e é combustível. Uma preocupação que se deve ter para o uso de madeiras é que sejam provenientes de reflorestamentos, evitando-se assim ao máximo os desmatamentos. Podem ser utilizadas diversas técnicas para trabalho como o jato de areia, entalhamento, usada com metal e até esculpidas.

- Vidro: muitas vezes chapas de vidro são colocadas sobre outro material usado na fabricação do elemento, protegendo-o e dando um aspecto diferenciado. Isso pode trazer problemas como, por exemplo, reflexo. Podem se quebrar com variação brusca de temperatura e pouco recomendável quanto há problemas de vandalismo. Podem ser gravadas com ácido, jato de areia ou entalhadas.

- $\quad$ Pedra: as pedras utilizadas com mais freqüência são o granito e mármore, tendo um aspecto natural muito forte. Sofre bastante com a ação de poluição atmosférica, oxidação de metais e efeitos de vegetação.

- Concreto: de fácil obtenção e moldável em qualquer lugar. 
Martins (1996), em sua tese de mestrado estudou um sistema de sinalização na cidade de Olinda-PE, lembra que ainda hoje não são encontrados muitos projetos de sinalização turístico-cultural e bibliografia especializada no Brasil, por esse motivo não há metodologia adotada por todos os profissionais, permitindo que estes desenvolvam e criem suas próprias formas de trabalho.

A autora sugere que no processo de elaboração de um projeto de sinalização, sejam realizadas investigações no local combinadas com os conhecimentos teóricos e técnicos, visitas técnicas em outros locais com situações semelhantes e entrevistas com os especialistas na área.

Sugere ainda que o planejamento comece com a definição e determinação da área a ser sinalizada. Determinada a área, o local também é especificado, com suas características históricas, artísticas e naturais. Em seguida busca-se dados para que se faça, sempre que possível, uma classificação de setores como, por exemplo, administrativo, natural, recreativo, informativo, comercial, científico, cultural e de diversão.

Em um segundo momento, listam-se os chamados equipamentos urbanos, se houver, e serviços da área como órgãos públicos, correios, telefonia, polícia, bombeiros, os de recreação como teatros, os de saúde como hospitais, os de transporte como pontos de táxi, de comunicação como rádio e telefones e finalmente os diversos como mercados, artesanato, sanitários e informações ao turistas. Listam-se, também, os recursos turísticos paisagísticos como mirantes e praias, arquitetônicos como museus e os monumentos como praças.

Buscam-se dados a respeito das características particulares do local como vegetação, topografia e hábitos dos usuários. No caso de locais com grande circulação, é importante que se faça uma análise do sistemas de transporte e sua eficiência, comodidade e segurança.

Outros elementos importantes na sinalização são a cor e a forma, que segundo os estudos desta autora, nos trabalhos de Rudolf Arnheim (1967), a forma supera a cor porque esta tem suas variações mais sutis, em graduações e aquela em tipos, tornando mais fácil a memorização. A identificação de elementos é mais eficiente quando a forma determina a diferença, as cores são instáveis podendo ser alteradas com a iluminação.

Outro elemento utilizado na sinalização, além da cor e forma, é o signo. Ele representa economia comunicativa, na maioria das vezes reduzindo textos, substituindo algum objeto e é associado à alguma idéia ou significado entendido pela maioria das pessoas ou mesmo determinado em alguma convenção

As cores são importantes no sistema, pois melhoram a sinalização à medida que se reconhece seu espaço na informação. O Manual de Sinalização Rodoviária do DNER (1997) indica o vermelho quando se pretende fazer uma proibição ou regulamentação, o verde para algo permitido ou orientações direcionais, o azul quando houver serviços auxiliares para os usuários. $O$ 
amarelo é recomendado para que se tenha atenção e o preto e branco para alguma regulamentação e informações complementares.

A cor permite que se faça a classificação temática das informações. De acordo com o tema, usa-se a cor que passa a ter seu significado relacionado, reduzindo muitas vezes a necessidade de leitura.

Martins (1996) ainda ressalta que na sinalização, um bom desenho apenas se faz notar, quando não há excesso de informações no mesmo elemento. As informações não devem ser simplesmente colocadas em um suporte pois não devem causar poluição visual e sim um ato de comunicação, sendo dosada de acordo com a capacidade de percepção e leitura dos sinais pelas pessoas.

O sistema de sinalização é um conjunto integrado, organizado e coerente de mensagens e seus respectivos suportes de transmissão.

Um sistema de sinalização bem implantado traz ao visitante bem-estar, tranqüilidade, conforto e segurança, aumentando a simpatia em relação ao local e sua administração e reduzindo os riscos de acidentes pela melhoria da circulação em sua área (Martins 1996).

Para a proposta de elaboração das imagens que irão compor o sistema, a informação a ser transmitida precisa ser clara, de percepção imediata, legível aos usuários e confiável, pois muitas decisões serão tomadas em sua função. Principalmente quando se tratar de ambientes naturais, deve ser o mais uniforme possível, evitando a concorrência com os atrativos (Martins 1996).

Um elemento gráfico que não utiliza a lingüística, mas pode tornar a comunicação mais eficaz é o pictograma. São desenhos que representam alguma situação, ação, local ou serviço e normalmente são formas que já têm um significado conhecido pelo público. Recomenda-se o uso limitado do pictograma, não devendo substituir completamente o texto: o melhor é que se use os dois (Martins 1996). 


\section{CAPÍTULO 3 - PROCEDIMENTOS METODOLÓGICOS}

A metodologia utilizada na pesquisa foi a de observação dos elementos já existentes no JBB e a comparação com recomendações de especialistas na área de sinalização gráfica.

A observação e comparação, segundo Linda Davidoff e Clifford Morgan (1983), são talvez os mais antigos métodos utilizados em experimentos científicos. A chamada observação natural consiste em observar acontecimentos sem manipulações, permitindo que o observador tenha a percepção do ocorrido e o interprete. Isso é feito normalmente pelos pesquisadores para uma investigação de comportamentos.

É verdade que existem outros métodos para se trabalhar na ciência com comportamentos, como a experimentação, mas para o presente trabalho, a observação e comparação foram suficientes à luz da bibliografia disponível.

A pesquisa foi realizada com visitas ao JBB, localizado no Setor de Mansões Dom Bosco, conjunto 12, entre dezembro de 2002 e março de 2003, em dias e horários aleatórios, distribuídos nos períodos da manhã e da tarde.

No JBB, a avaliação foi realizada somente na área de visitação delimitada nas figuras 01, 02, 03, 04, 05 e 06. A área da Estação Ecológica foi apenas observada e teve dois elementos fotografados para exemplificação da tipologia visual.

A história do JBB remonta a 1966 quando o Serviço de Pesquisas e Experimentação Florestal do Departamento de Recursos Naturais da Fundação Zoobotânica do Distrito Federal, iniciou a implantação da Estação Florestal Cabeça de Veado para que se estudassem as espécies nativas e as exóticas no DF. Em 19 de novembro de 1976 por meio do Dec. 3.441, foi criada a comissão para que fosse escolhida a área onde seria implantado o Jardim Botânico de Brasília. Em 1977 a comissão concluiu que a melhor área era da Estação Florestal Cabeça de Veado, com 526 ha pertencentes à Agência de Desenvolvimento do DF (Terracap).

A Terracap fez a doação do terreno à Secretaria de Agricultura e Produção e em 08 de maio de 1985, foi assinado o Dec. 7.038 criando o JBB, primeiro como departamento da FZDF. Em 26 de novembro foi criada a Estação Ecológica do JBB com área maior que a original, passando para 3.991 ha.

Com a extinção da FZDF, o JBB e a Estação Ecológica do JBB, passaram a ser subordinados ao Instituto de Ecologia e Meio Ambiente (IEMA) e em 03 de setembro de 1993 foi transformado em órgão relativamente autônomo, pela Lei 528 .

Desde sua criação o JBB sempre tem seus objetivos voltados para 0 Cerrado como um espaço de pesquisa, educação ambiental e lazer da população. 
Para o presente estudo, foram utilizadas as folhas 154 e 170, escala 1:10.000, do Sistema Cartográfico do Distrito Federal (SICAD), obtidas na Secretaria de Desenvolvimento Urbano e Habitação (SEDUH). Com base neste material foi produzido um mapa no programa Corel Draw 11

Neste mapa foi realizada a demarcação dos pontos onde se encontram os elementos de sinalização na área estudada, desde a entrada principal até a área restrita aos funcionários, incluindo as trilhas, o Centro de Visitantes e a área de piquenique.

Ainda neste mapa, foram locados trechos de trilhas não mais abertas à visitação. Para uma melhor análise da área, alguns pontos do mapa foram detalhados para que possibilitassem uma melhor leitura dos componentes.

Para os procedimentos comparativos, todos os tipos de elementos de sinalização foram documentados fotograficamente e posteriormente analisados à luz da bibliografia disponível. 


\section{CAPÍTULO 4 - RESULTADOS}

A pesquisa realizada foi o mapeamento dos pontos na área de visitação que possuem alguma sinalização e amostras foram obtidas por meio de fotografias exemplificando cada modelo de sinalização

Foram feitas 27 fotos de 18 modelos diferentes de elementos. Ao todo, 94 elementos foram cadastrados na área de visitação. Além destes, dois na área da Estação Ecológica e outros dois na área do Modelo Filogenético não fazem parte do cadastramento, mas foram citados e fotografados para exemplificação de modelos.

Estes pontos podem ser observados nas figuras 01, 02, 03, 04, 05 e 06 , onde são identificados em vermelho e código composto de número acompanhado por letra maiúscula. A identificação do código de cada elemento está na legenda da Tabela 01 na página 44.

Foram identificados os seguintes tipos de elemento:

- Elemento de identificação - corpo retangular e suporte de metal, de fundo verde, borda e letras brancas em material adesivo, com comprimento médio de $2 \mathrm{~m}$ e altura variando de acordo com a mensagem. Na tabela tem o código $\mathrm{n}^{\circ} \mathrm{B}$, totalizando três elementos e está exemplificado nas figuras $01 \mathrm{e}$ 15.

- $\quad$ Elemento de identificação - corpo retangular formado por lâminas e suporte de madeira, de cor natural, letras-caixa em metal pintado na cor branca, com 4,5 m de comprimento e $70 \mathrm{~cm}$ de altura. Traz ainda o símbolo do JBB como forma de assinatura na placa. $\mathrm{Na}$ tabela tem 0 código $\mathrm{n}^{\circ} \mathrm{A}$, totalizando um elemento e está exemplificado na figura 02 .

- $\quad$ Elemento de informação - corpo retangular e suporte de metal, de fundo branco, letras pretas em película adesiva e desenhos dos atrativos do parque, com comprimento médio de $35,5 \mathrm{~cm}$ e altura média de $55 \mathrm{~cm}$. Na tabela tem o código $\mathrm{B}$, totalizando um elemento e está exemplificado na figura 03.

- Elemento de regulamentação e informação - corpo retangular e suporte de madeira, de cor natural, com duas chapas de metal aparafusadas à madeira, de fundo branco, em uma delas desenho de animais e plantas semelhante à uma prancha em grafite e na outra letras pretas em material adesivo, com comprimento médio de $27,5 \mathrm{~cm}$ e altura média de $13,57 \mathrm{~cm}$ que contêm também o símbolo do JBB como assinatura. $\mathrm{Na}$ tabela têm o código $\mathrm{n}^{\circ}$ $\mathrm{F}$, totalizando 18 elementos e estão exemplificados na figura 04 .

- $\quad$ Elemento de informação - corpo retangular e suporte de metal, de fundo branco, borda preta, letras vermelhas em película adesiva, um leque colorido e um ponteiro branco, com comprimento médio de $79 \mathrm{~cm}$ e altura média de $40 \mathrm{~cm}$. Contém duas assinaturas, na forma dos símbolos do IBAMA e do Prevfogo. $\mathrm{Na}$ tabela tem o código $n^{\circ} \mathrm{B}$, totalizando um elemento e está exemplificado na figura 05. 
- Elemento de regulamentação - corpo retangular e suporte de madeira, de cor natural, letras gravadas em baixo relevo e pintadas com tinta branca, com comprimento médio de $59 \mathrm{~cm}$ e altura variando de acordo com a mensagem escrita que também pode ser de indicação e identificação. $\mathrm{Na}$ tabela tem o código $n^{\circ} \mathrm{A}$, totalizando 37 elementos e estão exemplificados na figura 06.

- $\quad$ Elemento de orientação - corpo retangular e suporte de metal, de fundo branco, letras pretas, desenho da área de visitação e a localização do parque no contexto de Brasília em material adesivo, com comprimento médio de $35,5 \mathrm{~cm}$ e altura média de $55 \mathrm{~cm}$. Traz a assinatura (símbolo) do JBB. $\mathrm{Na}$ tabela têm o código $n^{\circ} B$, totalizando dois elementos e estão exemplificados na figura 07.

- Elemento de identificação - corpo retangular e suporte de metal, de fundo azul, letras brancas em material adesivo e no canto inferior direito o símbolo do patrocinador, com comprimento médio de $6 \mathrm{~cm}$ e altura média de 10 $\mathrm{cm}$. Na tabela têm o código $\mathrm{n}^{\circ} \mathrm{B}$. Estes elementos não foram contabilizados, pois como identificam espécies vegetais, estão em grande número e em alguns casos adentrando a vegetação. Estão exemplificados na figura 08.

- $\quad$ Elemento de indicação e direcional - corpo retangular e suporte de metal, de fundo branco, letras verdes e signo direcional pintados, com $19,5 \mathrm{~cm}$ de comprimento e $35 \mathrm{~cm}$ de altura. Na tabela tem o código $n^{\circ} B$, totalizando um elemento e está exemplificado na figura 09.

- $\quad$ Elemento de identificação e regulamentação, corpo retangular e suporte de metal, de fundo branco, letras pretas em material adesivo, símbolo do Jardim Botânico no canto esquerdo, com comprimento médio de $116,5 \mathrm{~cm}$ e altura média de $40 \mathrm{~cm}$. Na legenda têm 0 código $\mathrm{n}^{\circ} \mathrm{B}$, totalizando quatro elementos e estão exemplificados na figura 10.

- Elemento de indicação e direcional - banner retangular de plástico, de fundo branco, letras pretas, seta vermelha, nos cantos superior e inferior direitos e inferior esquerdo símbolos de patrocinadores em material adesivo, com comprimento médio de $15,5 \mathrm{~cm}$ e altura média de $23,5 \mathrm{~cm}$, na legenda têm 0 código $n^{\circ} \mathrm{C}$, totalizando três elementos e estão exemplificados na figura 11.

- $\quad$ Elemento de indicação - corpo retangular e suporte de metal, de fundo marrom, letras brancas em material adesivo, com comprimento médio de $31,5 \mathrm{~cm}$ e altura média de $13,5 \mathrm{~cm}$. Os elementos desse modelo não foram contabilizados, pois estão na área da Estação Ecológica, não aberta à visitação e, portanto fora do estudo. O elemento foi citado e fotografado para exemplificação de modelo visual e está na figura 12.

- $\quad$ Elemento de advertência e regulamentação - corpo com formas de losango (advertência) ou circular (regulamentação) e suporte de metal, de cores de acordo com o Código Nacional de Trânsito. Na tabela têm o código $n^{\circ}$ $\mathrm{E}$, totalizando quatro elementos e estão exemplificados na figura 13. 
- $\quad$ Elemento de regulamentação - corpo retangular e suporte de metal, de fundo azul, borda e letras brancas, com comprimento médio de $2 \mathrm{~m}$ e altura variando de acordo com a mensagem. Na $v$ têm 0 código $n^{\circ} B$, totalizando um elemento e está exemplificado na figura 14.

- $\quad$ Elemento de indicação e direcional - corpo em forma de seta e suporte de madeira, de fundo verde, letras brancas em material adesivo, com comprimento de $1 \mathrm{~m}$ e altura $30 \mathrm{~cm}$. O elemento está presente na área restrita à funcionários do JBB, mas pode ser acessada pelos visitantes em ocasiões específicas. Na tabela tem o código $\mathrm{n}^{\circ} 29$, totalizando um elemento e está exemplificado na figura 16.

- $\quad$ Elemento de indicação e direcional - corpo em forma de seta e suporte de madeira, de fundo branco, letras amarelas pintadas, com comprimento médio de $1 \mathrm{~m}$ e altura média de $50 \mathrm{~cm}$. Na tabela tem o código $\mathrm{n}^{\circ}$ 27, totalizando um elemento e está exemplificado na figura 17.

As figuras com os exemplos dos modelos dos elementos presentes atualmente no JBB podem ser vistos a partir da página 23.

No mês de janeiro, teve início a implantação do conjunto de placas na área correspondente ao Modelo Filogenético, projeto que apresenta uma coleção de plantas dispostas segundo sua evolução. Este local está na área de visitação, ao lado do Centro de Visitantes, mas sua sinalização ainda não está completa, muitas placas não foram ainda colocadas. Por esse motivo, seus elementos não foram contabilizados, mas podem ser exemplificados nas figuras 18 e 19 e são descritos respectivamente como:

- um elemento de regulamentação - de corpo retangular, fundo verde, letras brancas em película adesiva, texto em dois idiomas e com o símbolo do Ministério do Meio Ambiente em seu canto inferior direito como assinatura. Tem comprimento de $20 \mathrm{~cm}$ e altura de $30 \mathrm{~cm}$ e está exemplificado na figura 18.

- $\quad$ um elemento de orientação - de corpo retangular, fundo branco, título com letras pretas, borda e letras do texto azuis, mapa da área, ilustrações de plantas em película adesivo e símbolo do Ministério do Meio Ambiente. Tem comprimento de $80 \mathrm{~cm}$ e altura de $1 \mathrm{~m}$ e está exemplificado na figura 19.

Foram observados também elementos com avarias por vandalismo e pela ação do tempo, que podem ser vistos nas figuras 20, 21, 22, 23, 24 e 25. Alguns elementos estavam dispostos de forma que o visitante tem dificuldades para visualizá-los. Na figura 26 a placa menor se encontra atrás da maior e pode não ser notada.

$\mathrm{Na}$ figura 27 o elemento está localizado em entroncamento de trilhas, mas está voltada somente para um sentido, além de estar atrás da vegetação de mesma cor.

Outro aspecto também observado foi a falta de elementos de sinalização em alguns cruzamentos bem como na via que dá acesso à entrada principal. 
$\mathrm{Na}$ área de visitação não foi seguido qualquer planejamento para o sistema presente, apesar de ter sido apresentado o Projeto de Complementação da Sinalização do JBB, pelo biólogo e consultor em Ecoturismo Rogério Dias em 1998. Os elementos foram e continuam sendo colocados de acordo com a necessidade.

Na Tabela 01 apresentada na página 37, estão dispostos os números das placas com o código de identificação demarcados nos mapas. A letra A é correspondente às placas feitas de madeira, a letra $B$ corresponde às placas feitas de metal, a letra $\mathrm{C}$ identifica os banners feitos de plástico, a letra $\mathrm{E}$ identifica as placas do Sistema de Sinalização do DNER e a letra F corresponde às placas de madeira que têm chapas de metal aparafusadas.

Na mesma tabela é possível observar o tipo de sinalização ao qual o elemento pertence. Foram identificados como de orientação, identificação, informação, indicação, regulamentação, advertência, segundo os autores consultados.

Ainda na tabela, é observada a mensagem escrita em cada elemento e em que mapa este pode ser encontrado. 


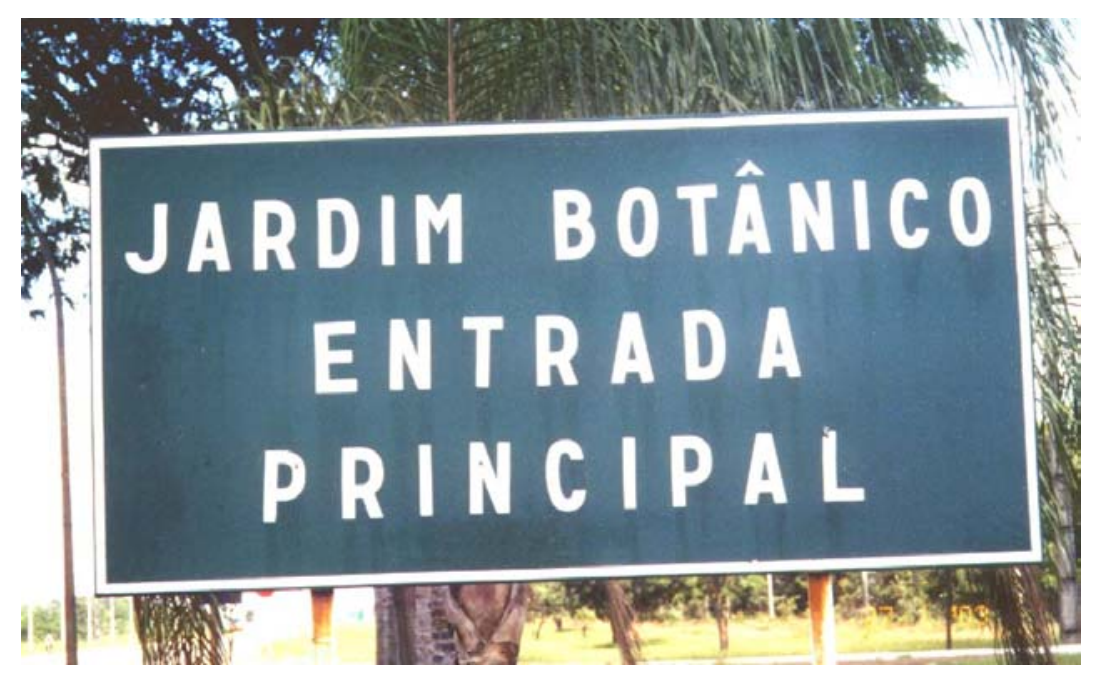

Fig. 01 - Elemento de identificação

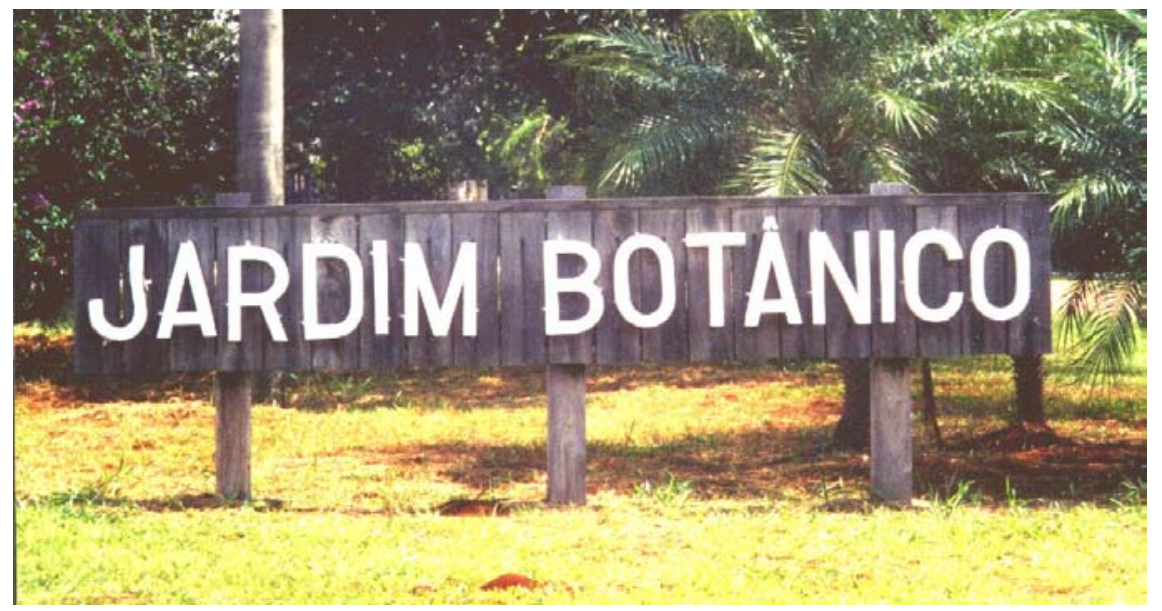

Fig. 02 - Elemento de identificação 


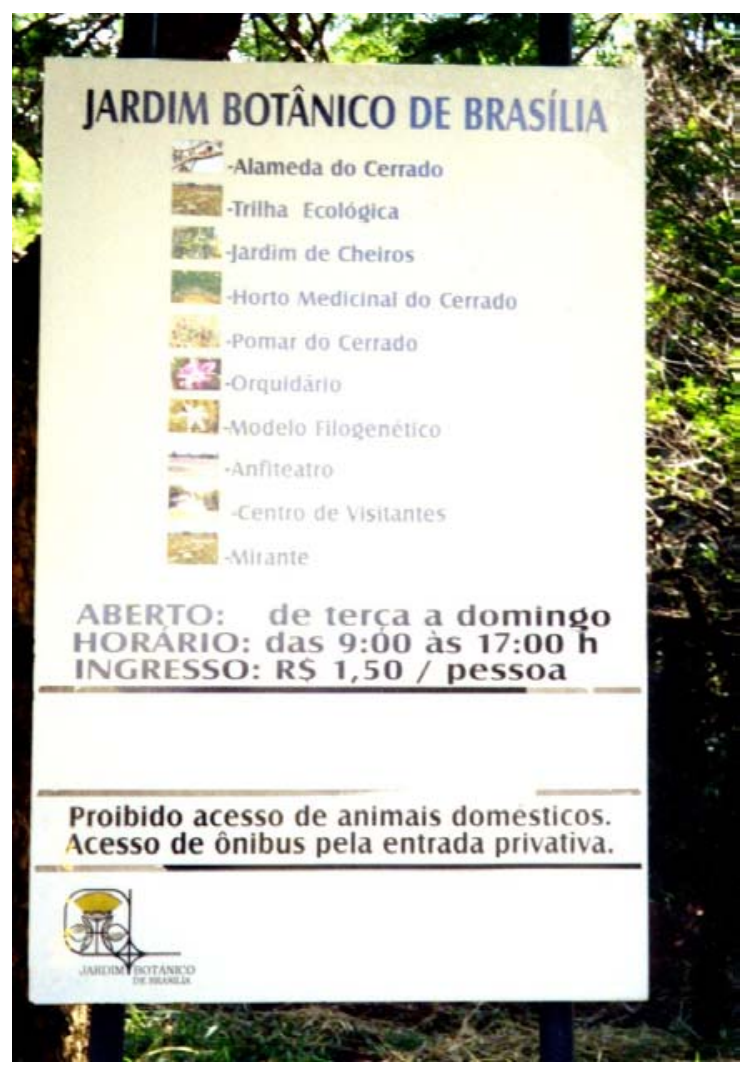

Fig. 03 - Elemento de informação e regulamentação

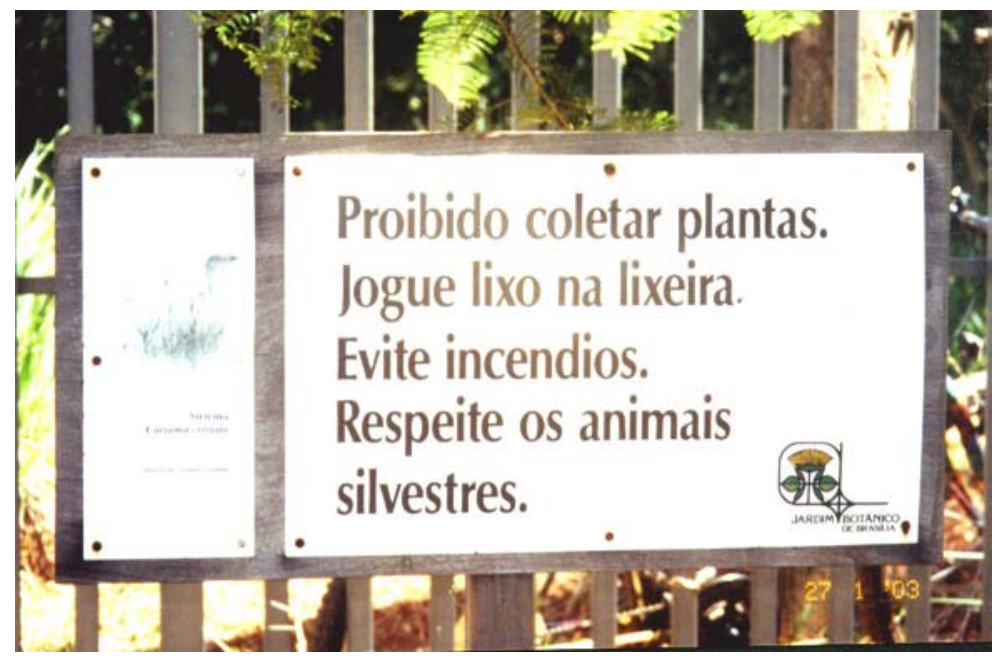

Fig. 04 - Elemento de regulamentação e informação 


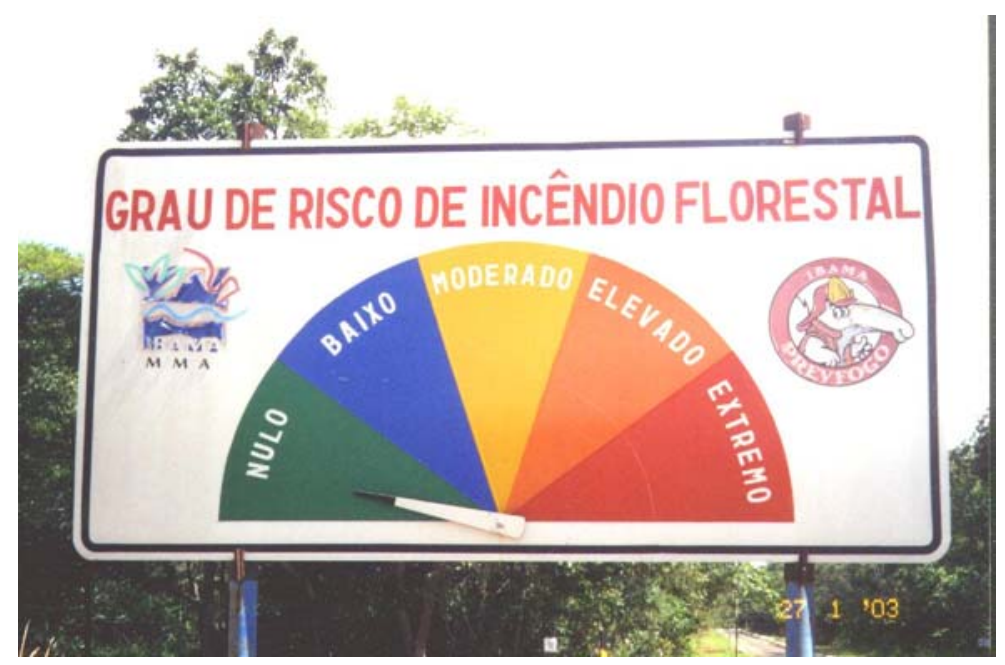

Fig. 05 - Elemento de informação e advertência

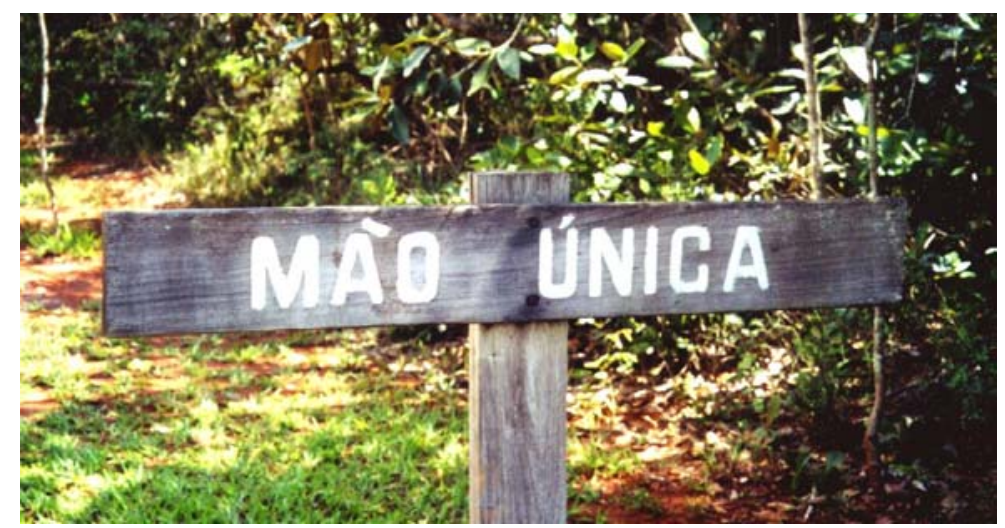

Fig. 06 - Elemento de regulamentação 


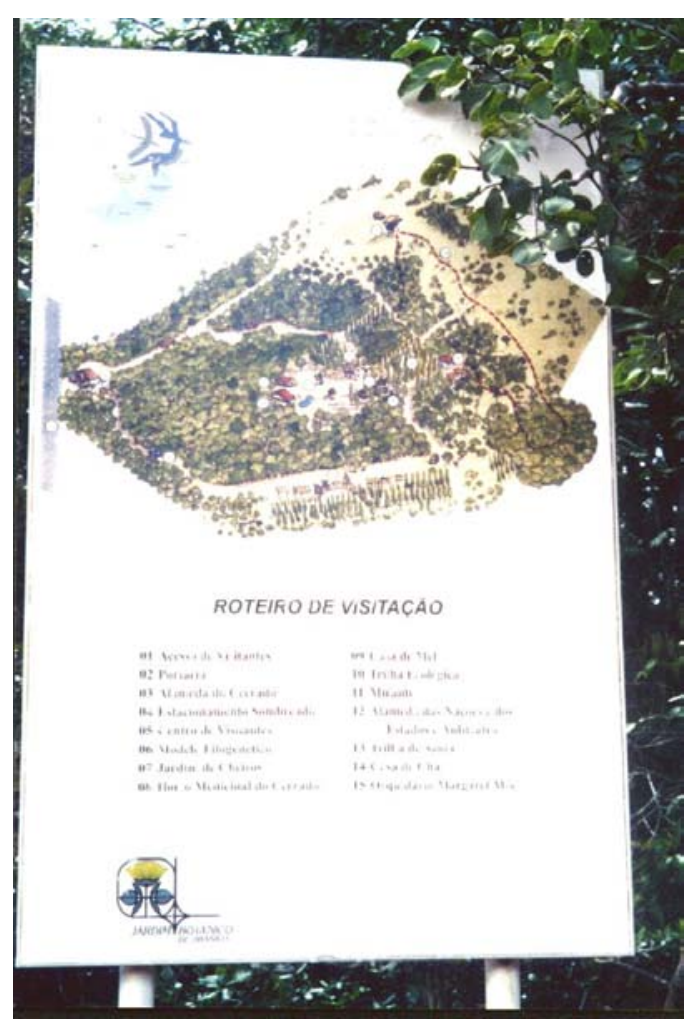

Fig. 07 - Elemento de orientação

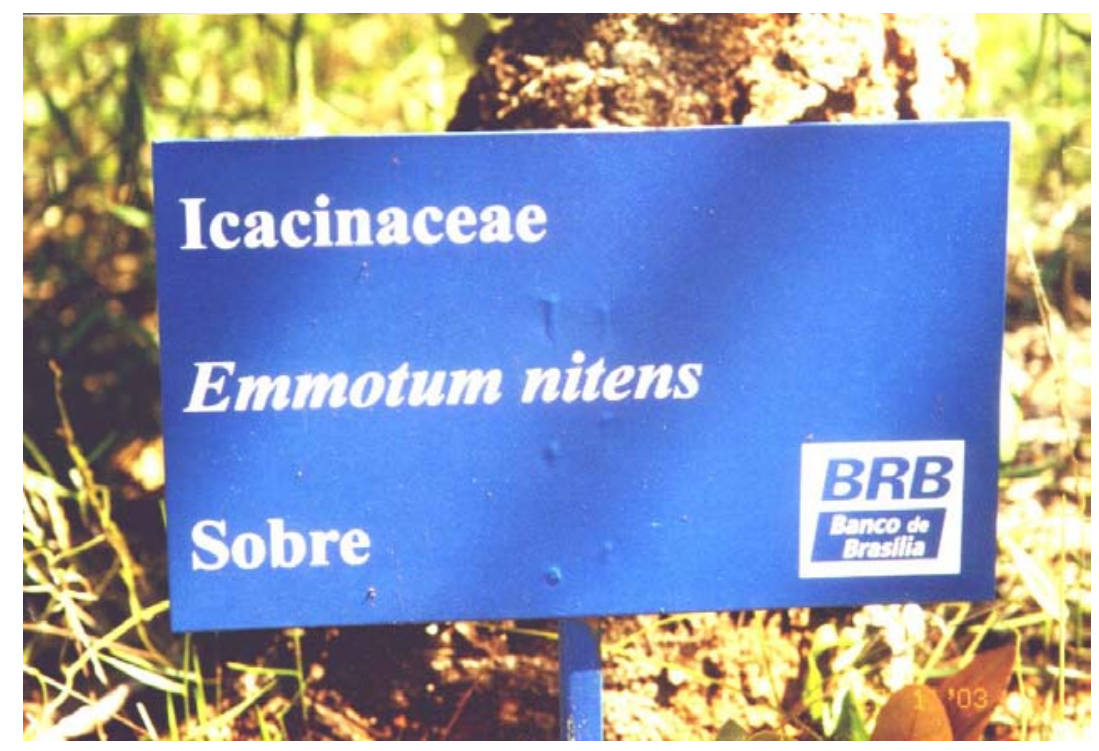

Fig. 08 - Elemento de identificação 


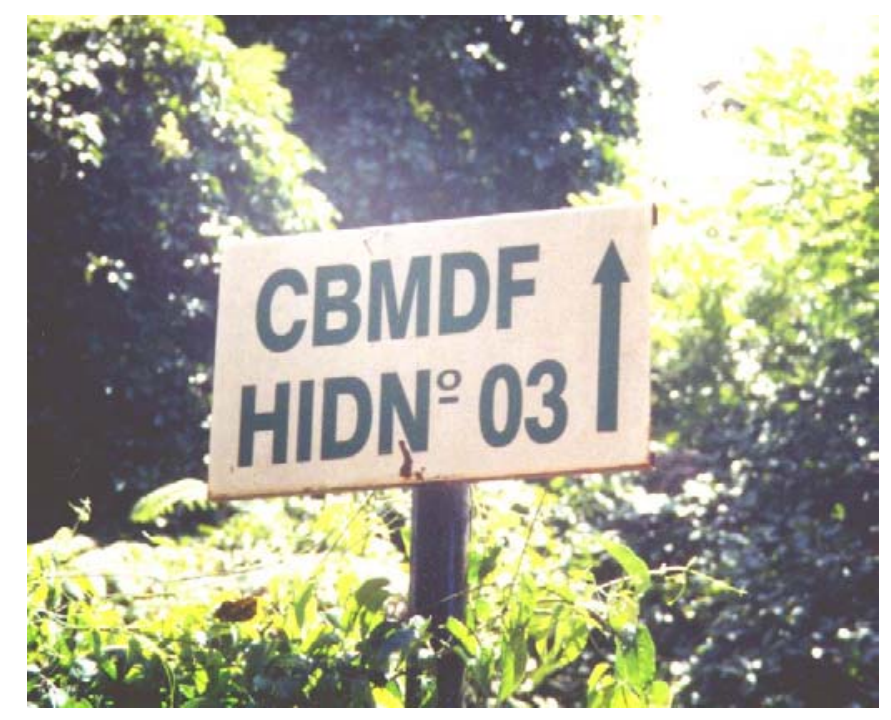

Fig. 09 - Elemento de indicação e direcional

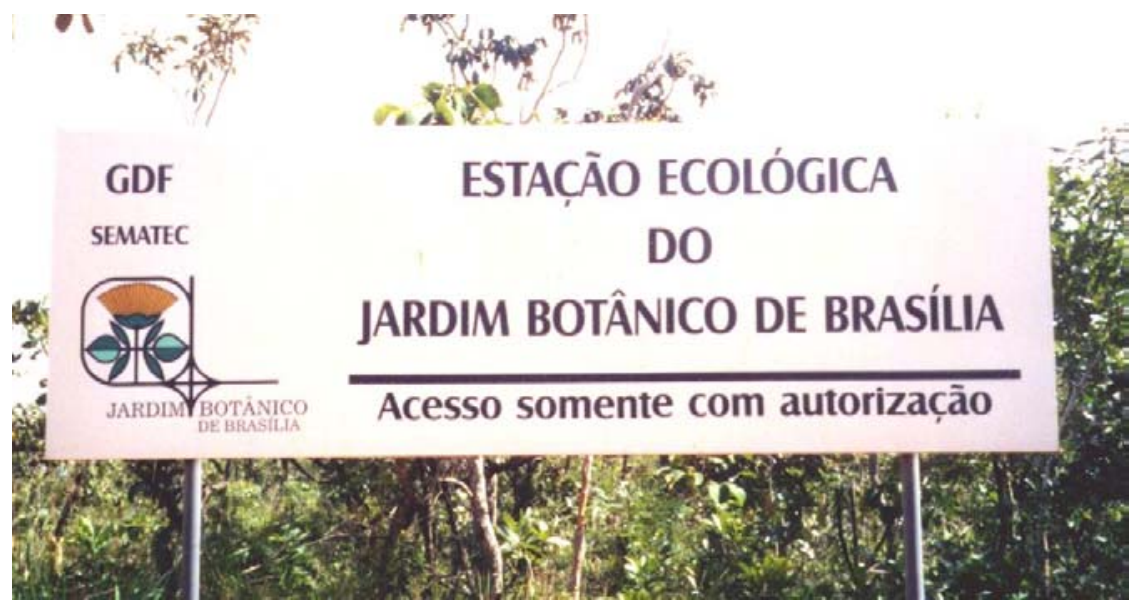

Fig. 10 - Elemento de identificação e regulamentação 


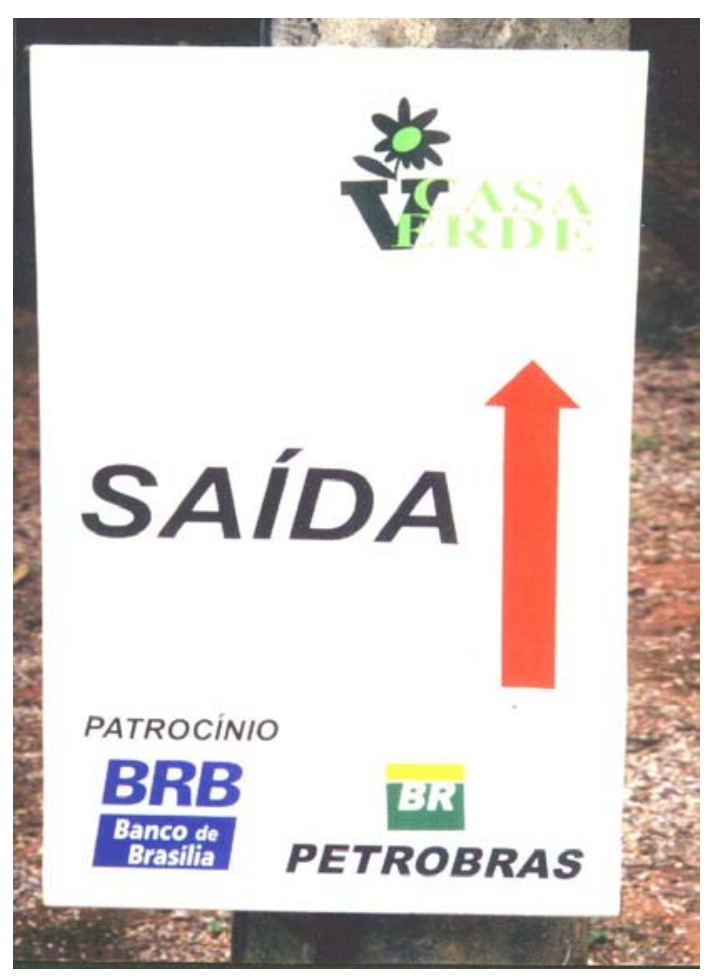

Fig. 11 - Elemento de orientação

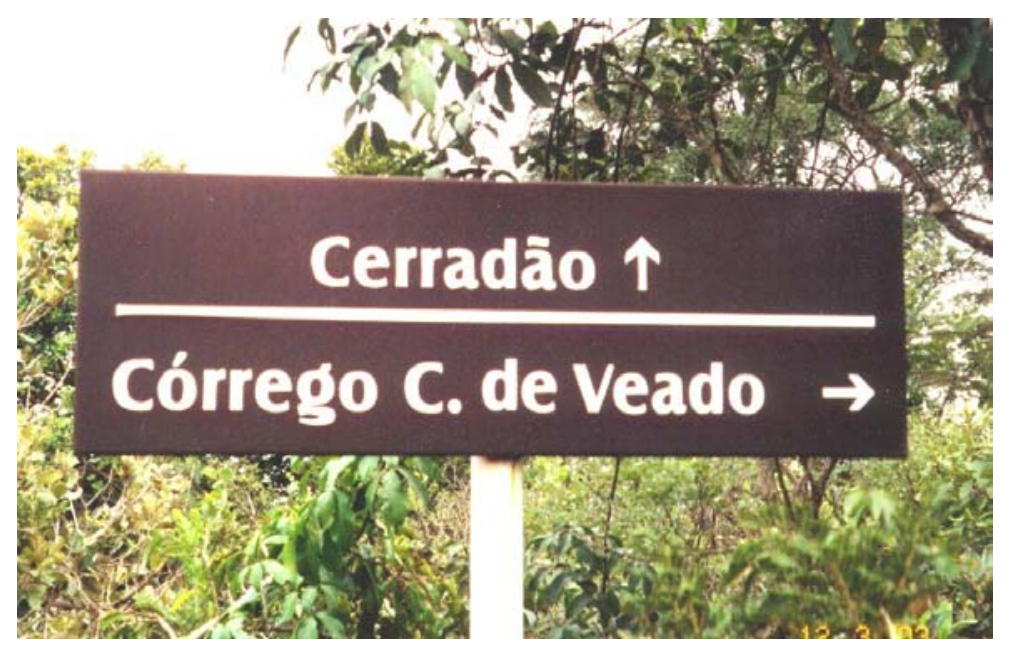

Fig. 12 - Elemento de identificação e indicação 


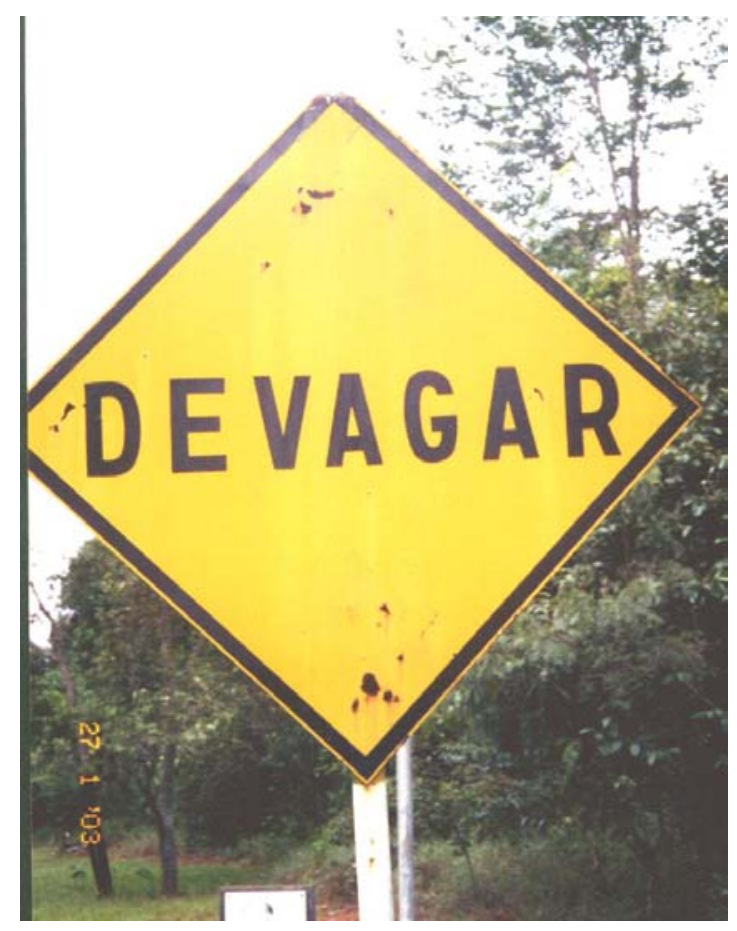

Fig. 13 - Elemento de regulamentação

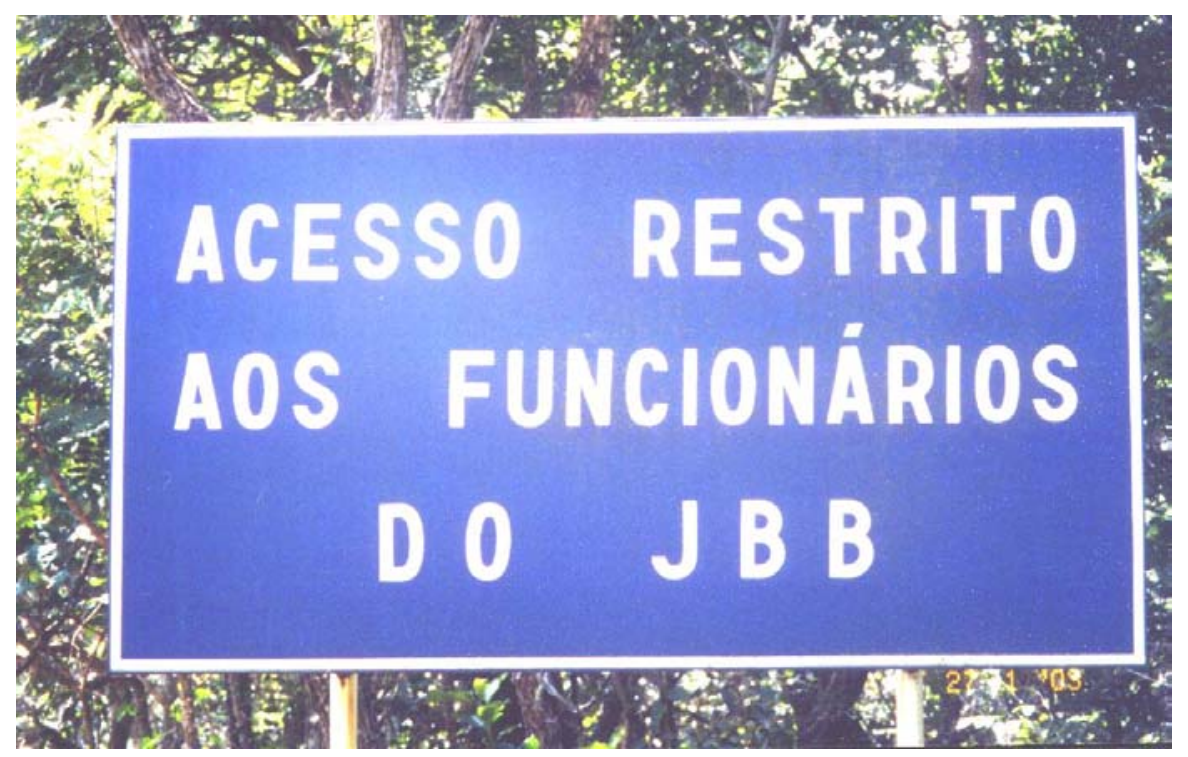

Fig. 14 Elemento de regulamentação 


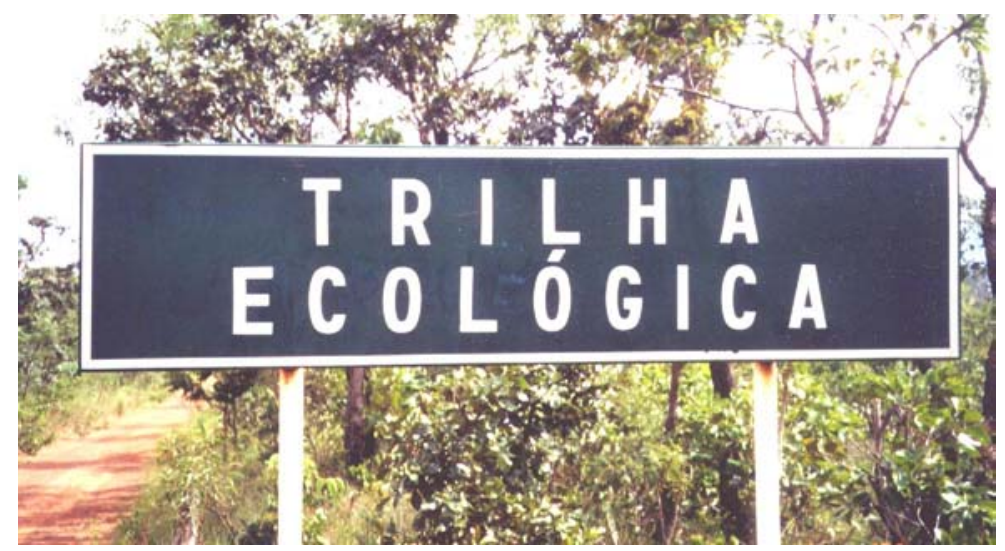

Fig. 15 - Elemento de identificação

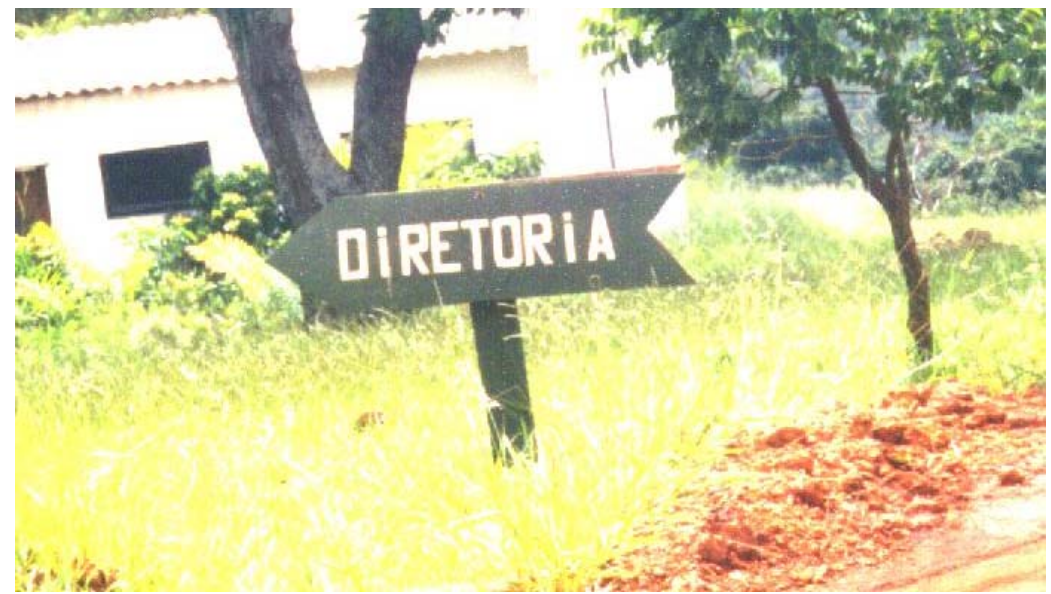

Fig. 16 - Elemento de indicação e direcional 


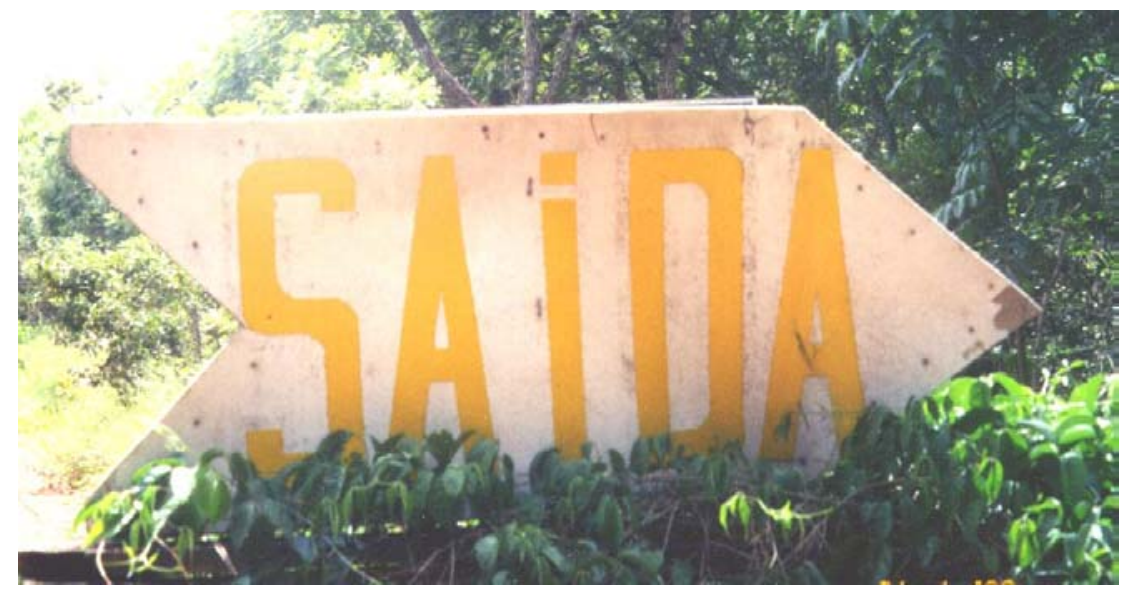

Fig. 17 - Elemento de indicação e direcional

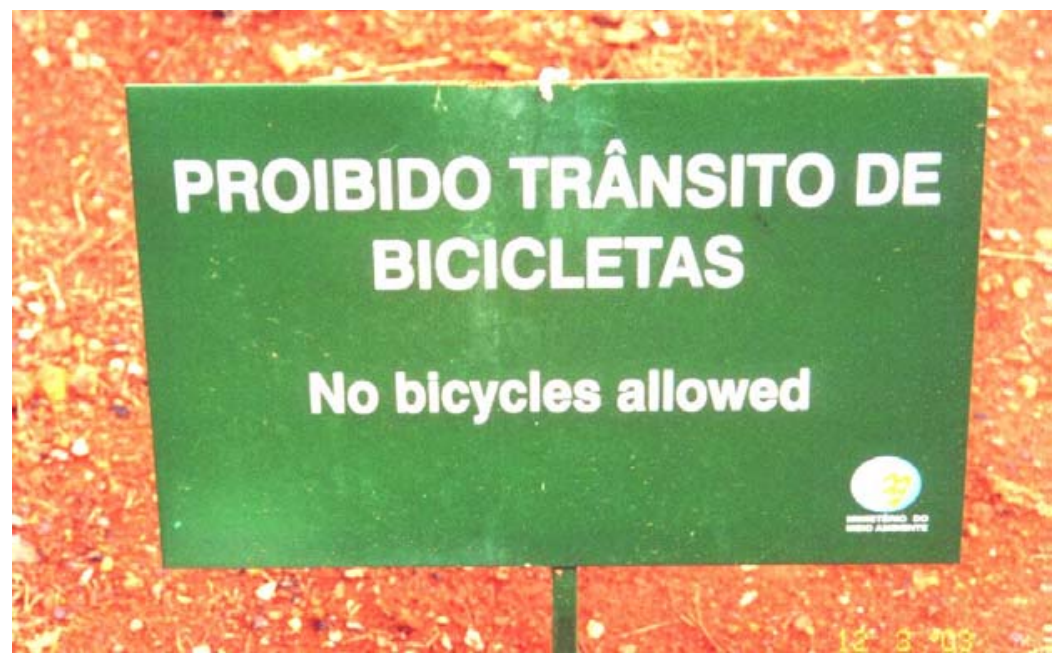

Fig. 18 - Elemento de regulamentação 


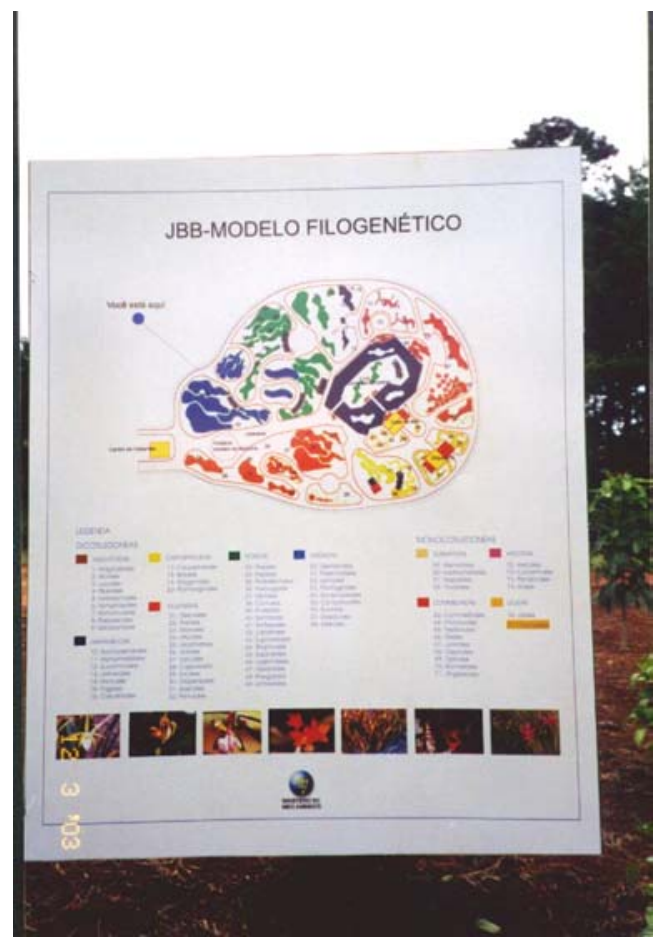

Fig. 19 - Elemento de orientação

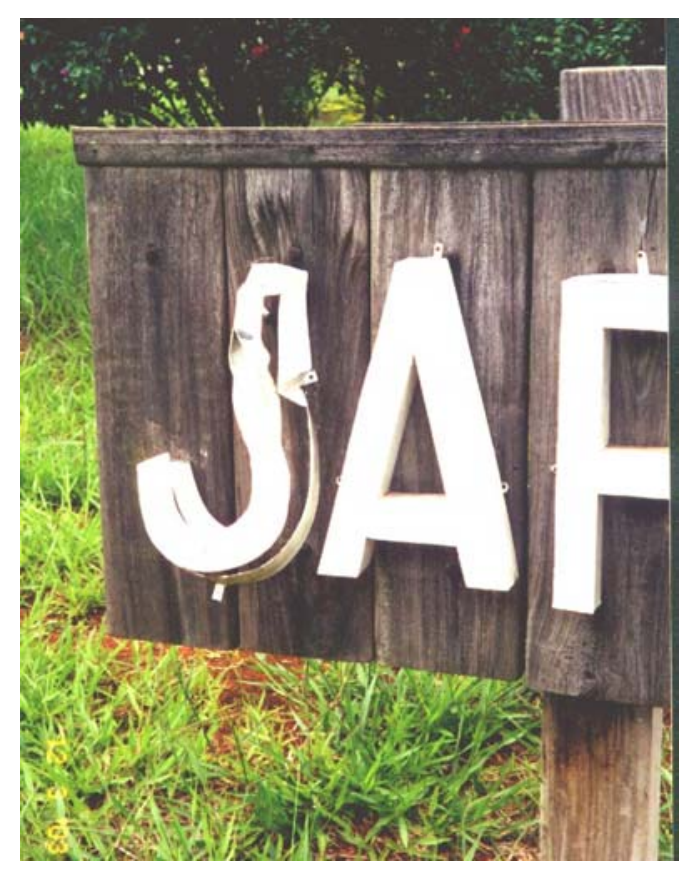

Fig. 20 - Elemento de identificação 


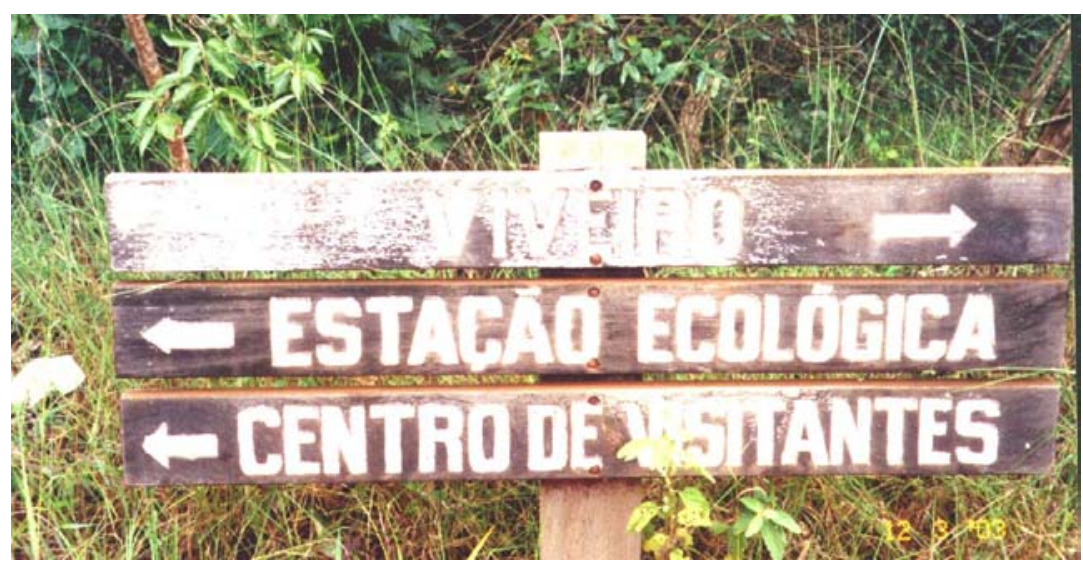

Fig. 21 - Elemento de indicação e direcional

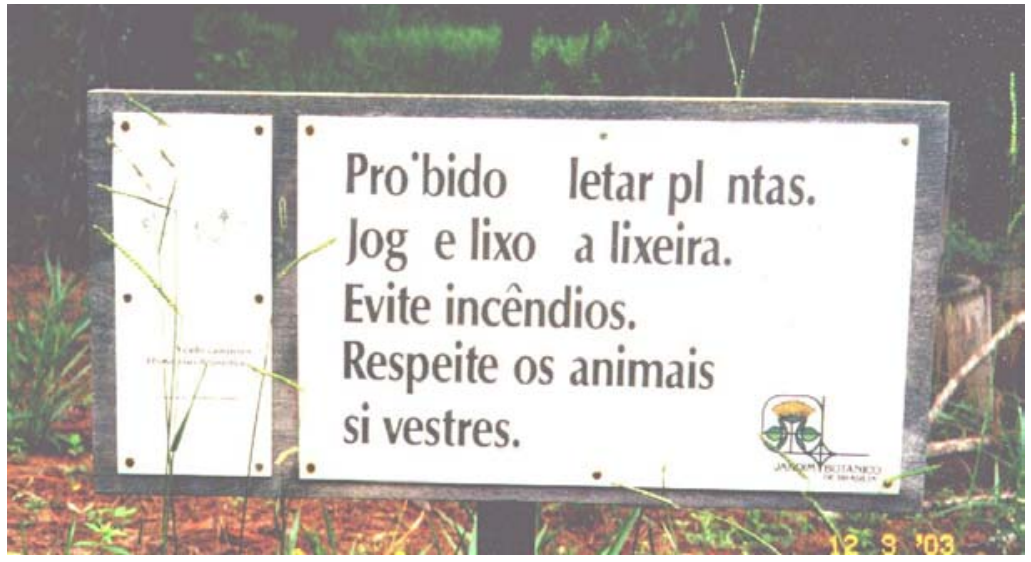

Fig. 22 - Elemento de regulamentação e informação 


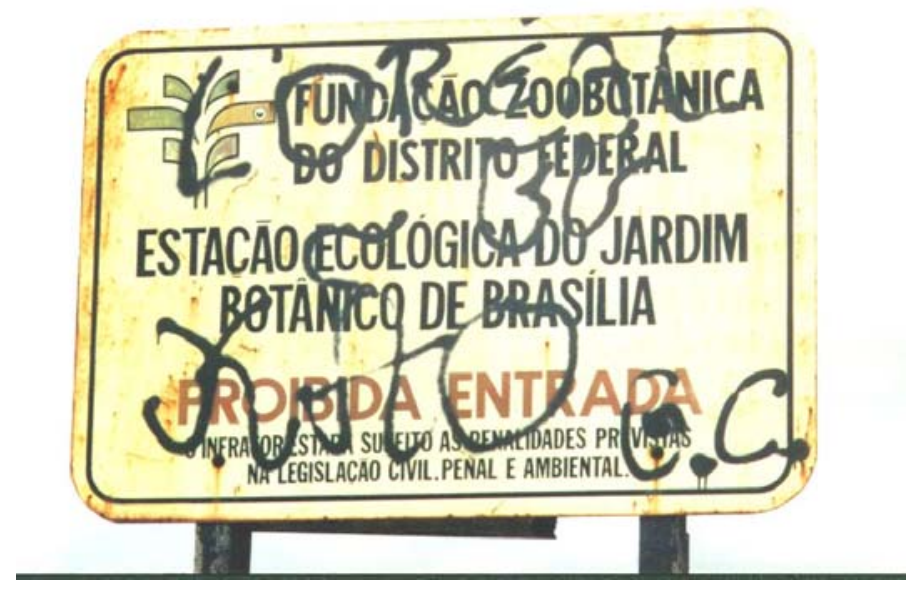

Fig. 23 - Elemento de identificação e regulamentação

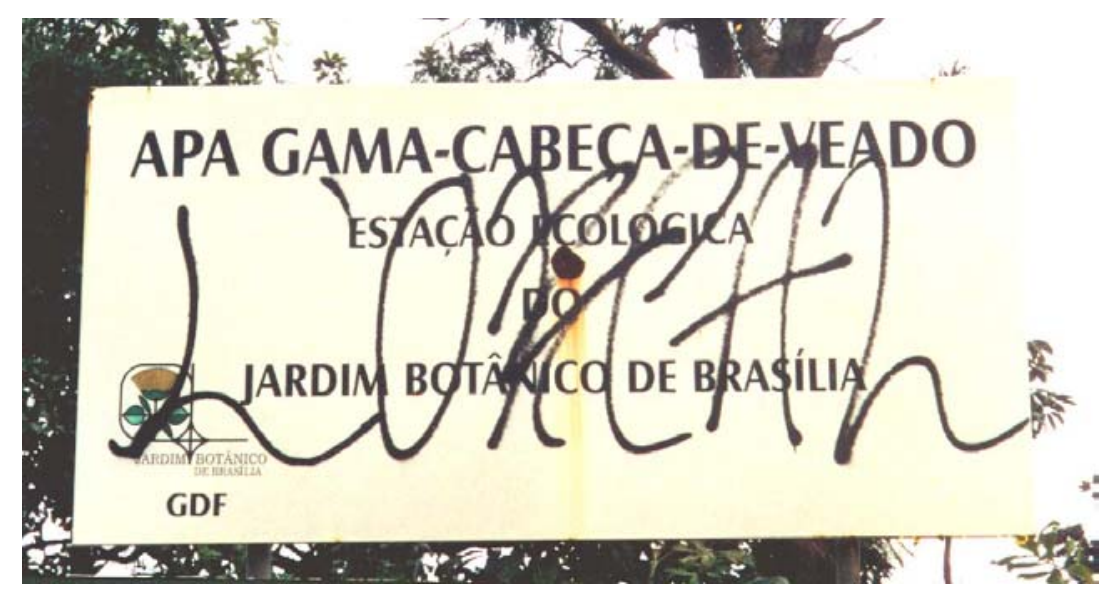

Fig. 24 - Elemento de identificação 


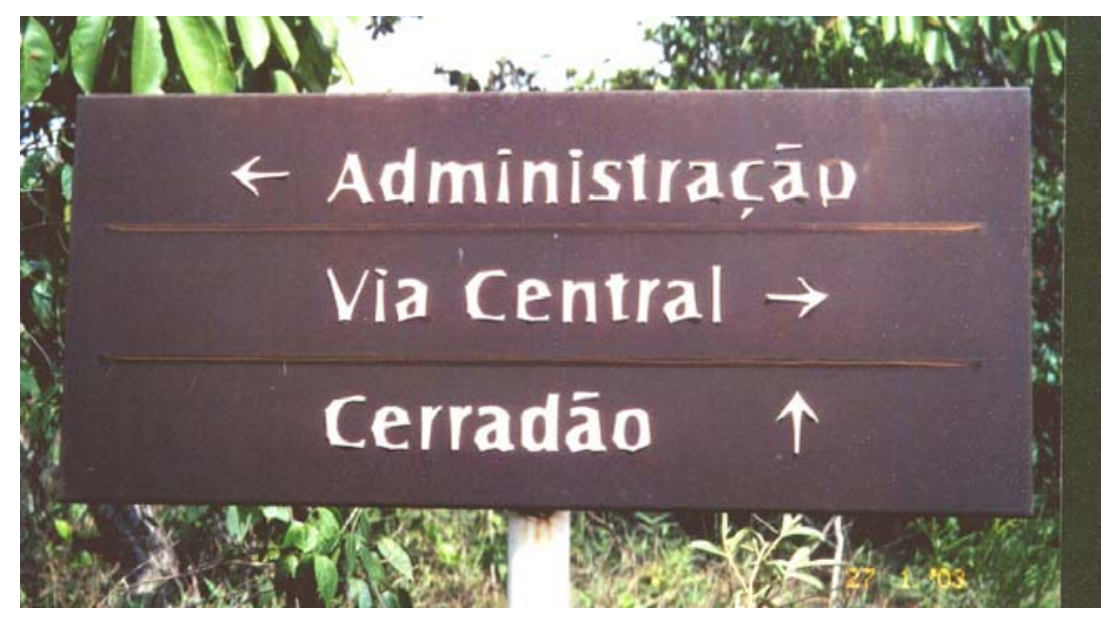

Fig. 25 - Elemento de indicação e direcional

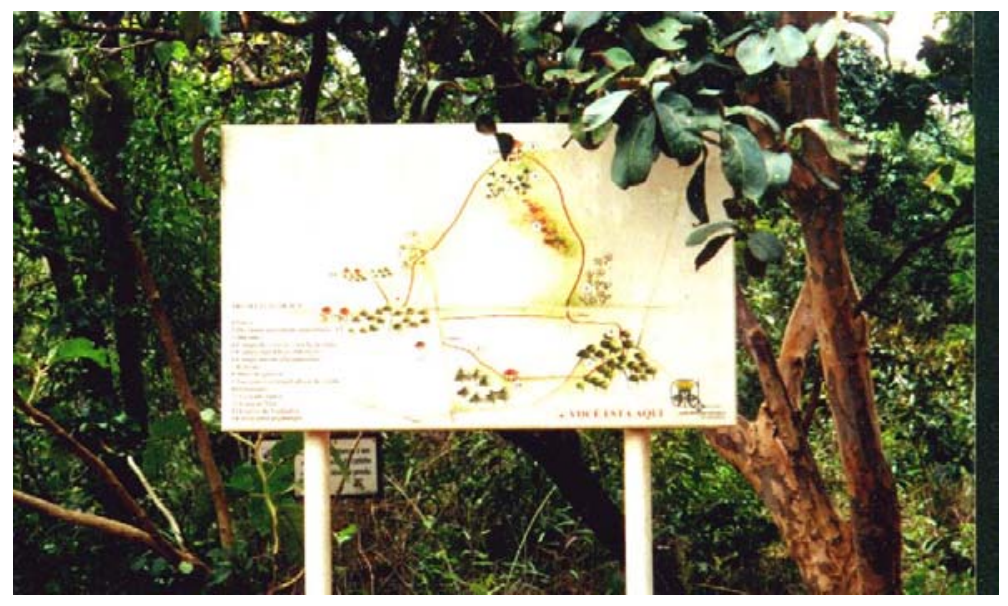

Fig. 26 - Elemento de orientação e informação 


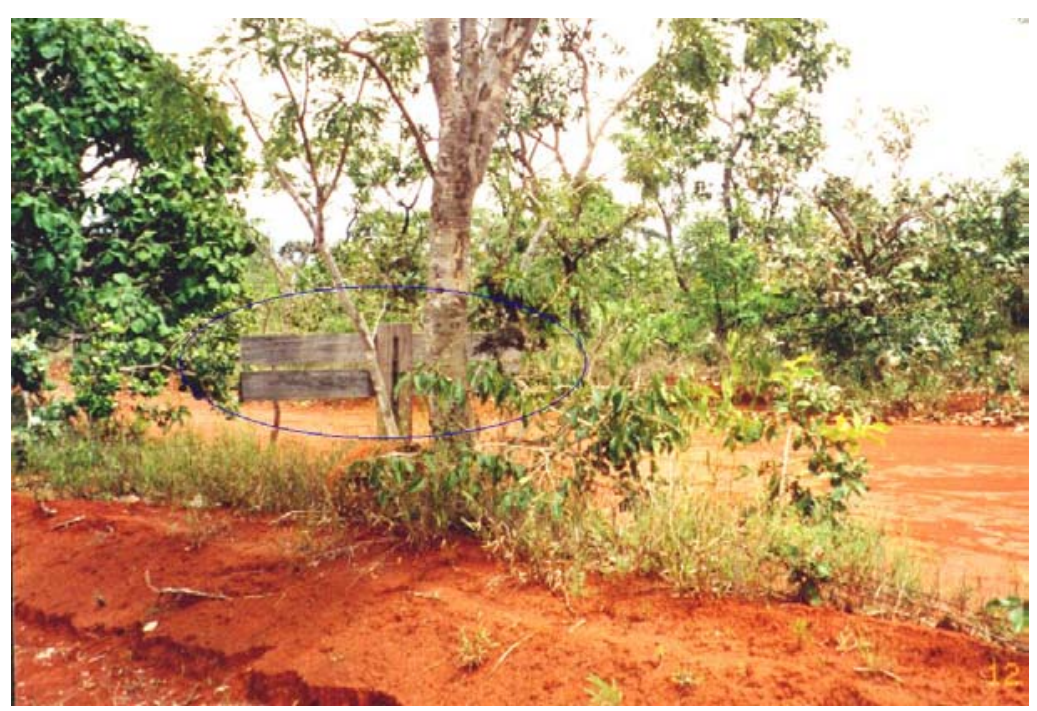

Fig. 27 - Elemento de indicação 
TABELA 01 - Sinalização existente no JBB

\begin{tabular}{|c|c|c|c|c|}
\hline $\mathbf{N}^{\mathbf{0}}$ & Código & Tipo de sinalização & Mensagem & Mapa \\
\hline 1 & $\mathrm{~B}$ & Identificação & $\begin{array}{l}\text { Jardim Botânico - Entrada } \\
\text { Principal }\end{array}$ & 01 \\
\hline 2 & A & Identificação & Jardim Botânico & 01 \\
\hline 3 & $B$ & $\begin{array}{l}\text { Informação e } \\
\text { regulamentação }\end{array}$ & Jardim Botânico de Brasília & 01 \\
\hline 4 & $\mathrm{~F}$ & Regulamentação & $\begin{array}{l}\text { Proibido coletar plantas/ Jogue } \\
\text { lixo na lixeira/ Evite incêndios/ } \\
\text { Respeite os animais silvestres }\end{array}$ & 01 \\
\hline 5 & $B$ & $\begin{array}{l}\text { Informação e } \\
\text { advertência }\end{array}$ & $\begin{array}{l}\text { Grau de risco de incêndio } \\
\text { florestal }\end{array}$ & 01 \\
\hline 6 & A & Regulamentação & Mão única & 01 \\
\hline 7 & $\mathrm{~B}$ & Orientação & Roteiro de Visitação & 01 \\
\hline 8 & $B$ & Identificação & Icacinaceae (variado) & $\begin{array}{l}\text { Toda a } \\
\text { área }\end{array}$ \\
\hline 9 & $B$ & Identificação & CBMDF-HID nº3 & 05 \\
\hline 10 & $B$ & $\begin{array}{l}\text { Identificação e } \\
\text { regulamentação }\end{array}$ & $\begin{array}{l}\text { Estação Ecológica do Jardim } \\
\text { Botânico de Brasília }\end{array}$ & 02 \\
\hline 11 & B & Indicação & Cerradão/ Córrego C. de Veado & $\begin{array}{l}\text { Estação } \\
\text { Ecológica }\end{array}$ \\
\hline 12 & $\mathrm{~B}$ & Indicação & Trilha Ecológica & 02 \\
\hline 13 & $\mathrm{C}$ & Orientação & Saída & 05 \\
\hline 14 & B & Advertência & Devagar & 01 \\
\hline 15 & $\mathrm{~F}$ & Ilustração & (desenho de animais) & 01 \\
\hline 16 & $\mathrm{~F}$ & Informação & $\begin{array}{l}\text { Conhecer a natureza é um ato } \\
\text { de carinho e ousadia, ciência e } \\
\text { poesia }\end{array}$ & 01 \\
\hline 17 & $A$ & $\begin{array}{l}\text { Identificação e } \\
\text { indicação }\end{array}$ & $\begin{array}{l}\text { Estacionamento/ Centro de } \\
\text { Visitantes/ Modelo Filogenético }\end{array}$ & 01 \\
\hline 18 & A & Identificação & Área de Pique Nique & 03 \\
\hline 19 & A & $\begin{array}{l}\text { Regulamentação e } \\
\text { Indicação }\end{array}$ & $\begin{array}{l}\text { Contra Mão/ Mirante/ Trilha } \\
\text { Ecológica }\end{array}$ & 01 \\
\hline 20 & A & Identificação & Estacionamento & 01 \\
\hline 21 & $A$ & Indicação & $\begin{array}{l}\text { Centro de Visitantes/ Horto } \\
\text { Medicinal/ Jardim de cheiros }\end{array}$ & 04 \\
\hline 22 & $\mathrm{~B}$ & Orientação & Roteiro de Visitação & 04 \\
\hline 23 & A & Identificação & Jardim de Cheiros & 04 \\
\hline 24 & A & Informação & Centro de Visitantes & 04 \\
\hline 25 & $\mathrm{~F}$ & Identificação & Jardim Botânico de Brasília & 04 \\
\hline 26 & B & Regulamentação & $\begin{array}{l}\text { Acesso Restrito aos } \\
\text { Funcionários do JBB }\end{array}$ & 05 \\
\hline 27 & A & Indicação & Saída & 05 \\
\hline \multicolumn{5}{|c|}{ Não existe o elemento 28} \\
\hline 29 & A & Indicação & Diretoria & 06 \\
\hline 30 & B & Indicação & Educação Ambiental & 06 \\
\hline 31 & A & Identificação & Educação Ambiental & 06 \\
\hline 32 & B & Identificação & Fabriqueta & 06 \\
\hline 33 & $A$ & Identificação & Fabriqueta & 06 \\
\hline 34 & A & Identificação & Diretoria & 06 \\
\hline 35 & $A$ & Identificação & Diretoria & 06 \\
\hline 36 & A & Identificacão & Estacão Ecolóqica & 02 \\
\hline 37 & $A$ & Indicação & Trilha Ecológica/ Mirante & 02 \\
\hline
\end{tabular}




\begin{tabular}{|c|c|c|c|c|}
\hline $\mathbf{N}^{\circ}$ & Código & Tipo de sinalização & Mensagem & Mapa \\
\hline 38 & A & Indicação & $\begin{array}{l}\text { Mirante/ Alameda das Nações/ } \\
\text { Cerradão }\end{array}$ & 01 e 02 \\
\hline 39 & $A$ & Indicação & Centro de Visitantes & 01 e 02 \\
\hline 40 & B & Identificação & Mirante & 02 \\
\hline 41 & B & $\begin{array}{l}\text { Identificação e } \\
\text { regulamentação }\end{array}$ & $\begin{array}{l}\text { Estação Ecológica/ Entrada } \\
\text { Proibida }\end{array}$ & 02 \\
\hline 42 & A & Identificação & Estação Ecológica & 02 \\
\hline 43 & A & Indicação & Mirante & 02 \\
\hline 44 & A & Indicação & Mirante/ Administração & 02 \\
\hline \multicolumn{5}{|c|}{ Não existe o elemento 45} \\
\hline 46 & A & Indicação & Administração & 02 \\
\hline 47 & $A$ & Indicação & $\begin{array}{l}\text { Centro de Visitantes/ Estação } \\
\text { Ecológica }\end{array}$ & 02 \\
\hline 48 & A & Indicação & $\begin{array}{l}\text { Administração/ Estação } \\
\text { Ecológica }\end{array}$ & 02 \\
\hline 49 & A & Indicação & Estação Ecológica/ Mirante & 02 \\
\hline 50 & $A$ & Indicação & $\begin{array}{l}\text { Estação Ecológica/ } \\
\text { Administração }\end{array}$ & 02 \\
\hline 51 & $A$ & Indicação & $\begin{array}{l}\text { Administração/ Centro de } \\
\text { Visitantes }\end{array}$ & 02 \\
\hline 52 & B & Identificação & Estação Ecológica & 01 \\
\hline \multicolumn{5}{|c|}{ Não existe o elemento 53} \\
\hline 54 & $\mathrm{~F}$ & Informação & Preserve o Cerrado & 01 \\
\hline 55 & $\mathrm{~F}$ & Ilustração & (desenho de aves) & 01 \\
\hline 56 & $\mathrm{~F}$ & Ilustração & (desenho de vegetação) & 01 \\
\hline 57 & $\mathrm{~F}$ & Informação & $\begin{array}{l}\text { Barbatimão/ Essa árvore foi } \\
\text { vítima da falta de respeito com a } \\
\text { natureza }\end{array}$ & 01 \\
\hline 58 & A & Regulamentação & Contra Mão & 01 \\
\hline 59 & $\mathrm{~F}$ & Informação & $\begin{array}{l}\text { Da natureza nada se tira a não } \\
\text { ser fotografias, nada se deixa a } \\
\text { não ser pegadas e nada se leva } \\
\text { a não ser recordação }\end{array}$ & 01 \\
\hline 60 & A & Advertência & Devagar & 01 \\
\hline 61 & $E$ & Advertência & Ondulação & 01 \\
\hline 62 & $\mathrm{~F}$ & Informação & $\begin{array}{l}\text { Motorista, a preferência é dos } \\
\text { animais }\end{array}$ & 01 \\
\hline 63 & $\mathrm{~F}$ & Informação & $\begin{array}{l}\text { Conhecer a natureza é um ato } \\
\text { de carinho e ousadia, ciência e } \\
\text { poesia }\end{array}$ & 03 \\
\hline 64 & $\mathrm{~F}$ & Informação & Fumante: Segure as pontas & 03 \\
\hline 65 & $\mathrm{~F}$ & Regulamentação & $\begin{array}{l}\text { Proibido coletar plantas/ Jogue o } \\
\text { lixo na lixeira/ Evite incêndios/ } \\
\text { Respeite os animais }\end{array}$ & 03 \\
\hline 66 & A & Identificação & Sanitários & 03 \\
\hline 67 & $\mathrm{E}$ & Advertência & Ondulação & 01 e 02 \\
\hline 68 & A & Indicação & $\begin{array}{l}\text { Alameda das Nações e dos } \\
\text { Estados/ Anfiteatro/ Saída }\end{array}$ & 05 \\
\hline 69 & A & Indicação & Saída & 05 \\
\hline 70 & A & Advertência & Devagar & 01 \\
\hline
\end{tabular}




\begin{tabular}{|c|c|c|c|c|}
\hline $\mathbf{N}^{\circ}$ & Código & Tipo de sinalização & Mensagem & Mapa \\
\hline 71 & $\mathrm{~F}$ & Informação & $\begin{array}{l}\text { Motorista, a preferência é dos } \\
\text { animais }\end{array}$ & 01 \\
\hline 72 & $A$ & Indicação & $\begin{array}{l}\text { Alameda das Nações e dos } \\
\text { Estados/ Anfiteatro/ Saída }\end{array}$ & 01 \\
\hline 73 & A & Identificação & $\begin{array}{l}\text { Avenida das Nações e dos } \\
\text { Estados }\end{array}$ & 01 \\
\hline 74 & $\mathrm{E}$ & Advertência & Devagar & 01 \\
\hline 75 & A & Regulamentação & Mão Única & 01 \\
\hline 76 & A & Identificação & Ponto de parada & 01 \\
\hline \multicolumn{5}{|c|}{ Não existe o elemento 77} \\
\hline 78 & $\mathrm{E}$ & Regulamentação & (símbolo de contra mão) & 01 \\
\hline 79 & A & Identificação & Anfiteatro & 01 \\
\hline 80 & A & Identificação & Ponto de parada & 01 \\
\hline 81 & $\mathrm{~F}$ & Informação & $\begin{array}{l}\text { Preserve o cerrado, a savana } \\
\text { mais rica do planeta }\end{array}$ & 01 \\
\hline 82 & A & Advertência & Devagar & 01 \\
\hline 83 & A & Indicação & Saída & 01 \\
\hline 84 & $\mathrm{~F}$ & Ilustração & (desenho de vegetação) & 01 \\
\hline 85 & C & Informação & $\begin{array}{l}\text { Visitante, a preferência é dos } \\
\text { animais }\end{array}$ & 01 \\
\hline 86 & $\mathrm{~F}$ & Ilustração & (desenho de vegetação) & 01 \\
\hline 87 & C & Informação & Fumante: segure as pontas & 01 \\
\hline 88 & $A$ & Advertência & Devagar & 01 \\
\hline 89 & C & Informação & $\begin{array}{l}\text { Visitante, a preferência é dos } \\
\text { animais }\end{array}$ & 01 \\
\hline 90 & $\mathrm{E}$ & Regulamentação & Símbolo de sentido obrigatório & 01 \\
\hline 91 & $\mathrm{E}$ & Advertência & Devagar & 01 \\
\hline 92 & $\mathrm{~F}$ & Regulamentação & $\begin{array}{l}\text { Proibido coletar plantas/ Jogue } \\
\text { lixo na lixeira/ proibida a entrada } \\
\text { de animais domésticos/ Evite } \\
\text { incêndios }\end{array}$ & 04 \\
\hline 93 & B & Identificação & Educação Ambiental & 06 \\
\hline 94 & B & Orientação & (mapa das trilhas) & 02 \\
\hline 95 & $\mathrm{~F}$ & Informação & $\begin{array}{l}\text { Conhecer a natureza é um ato } \\
\text { de carinho e ousadia, ciência e } \\
\text { poesia }\end{array}$ & 02 \\
\hline 96 & $\mathrm{~F}$ & Ilustração & (desenho de vegetação) & 02 \\
\hline 97 & $\mathrm{~F}$ & Informação & (desenho de garoto índio) & 01 \\
\hline 98 & $\mathrm{~F}$ & Ilustração & (desenho de garoto índio) & 01 \\
\hline
\end{tabular}




\section{CAPÍTULO 5 - DISCUSSÃO DOS RESULTADOS DA PESQUISA}

Um dos aspectos observados nos resultados da pesquisa foi a localização dos elementos, que não estão dispostos da melhor forma.

A via que dá acesso ao Jardim Botânico, localizado no conjunto 12 do Setor de Mansões Dom Bosco, é a EPCV (DF-035), que por sua vez, pode ser acessada tanto pela EPDB (DF-025) como pela EPCT (DF-001). Na DF-035 não existe qualquer placa indicando ou orientando sobre a aproximação de local, a não ser a da entrada principal, que tem a identificação 1B na tabela 01. Na DF-025 há uma placa no semáforo da QI 23 e outra no viaduto da QI 11, vindo da Ponte Costa e Silva no Lago Sul.

Estas placas permitem que o visitante tome as direções corretas, mas tanto a da entrada principal como a do semáforo são exatamente nas interseções, não dando a chance aos visitantes que estão conduzindo algum veículo de se prepararem para fazer a manobra tomando a faixa de desaceleração.

Desta forma, o condutor pode passar pela entrada sem ter visto a placa, ficando comprometida sua tomada de decisão e sua segurança.

A legibilidade da sinalização gráfica depende da velocidade em que os motoristas estão e da distância necessária para o reconhecimento da mensagem. Com uma velocidade de $60 \mathrm{~km} / \mathrm{h}$, que é a velocidade máxima da DF-035, é necessário um sinal a pelo menos $60 \mathrm{~m}$ de distância, para que o motorista possa reduzir a velocidade e entrar.

A Orientação para Sinalização Visual de Unidades de Conservação Federais, que foi adotada para a elaboração das propostas a seguir, recomenda que os elementos de aproximação, ou seja, a pré-sinalização, devem apresentar a mensagem, que no caso é o nome do JBB, a indicação da distância a ser percorrida e um signo direcional.

O fundo da placa deve ser marrom, com letras e signo direcional brancos e o alfabeto padrão usado pelo DNER. A seguir é apresentado o modelo de acordo com a orientação.

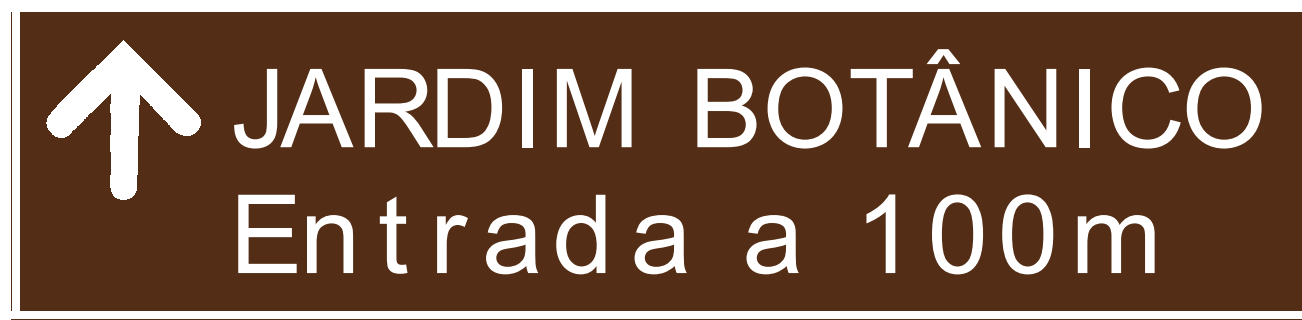

$2,50 \mathrm{~m}$

modelo 01 
Nas figuras 01 e 02 podem ser observados os pontos onde foram demarcados os elementos que têm sua implantação proposta, com uma marcação de cor azul, identificados pela letra $\mathrm{P}$ e um número que corresponde a uma mensagem. São locais onde não existe nenhum tipo de sinal e sua ausência pode causar desconforto e dúvida ao visitante. As mensagens destes elementos estão na tabela 02.

A unidade visual deve se estender ao uso das cores, do alfabeto, tamanhos e formas. Essa unidade não foi alcançada, pois não houve padronização destes outros aspectos em todos os elementos do JBB.

Na figura 01, por exemplo, na entrada principal um pouco antes da portaria, a placa é de metal, com fundo verde e letras brancas todas em caixa alta. As recomendações são as mesmas da pré-sinalização, nome do JBB e um signo direcional identificando onde é a entrada.

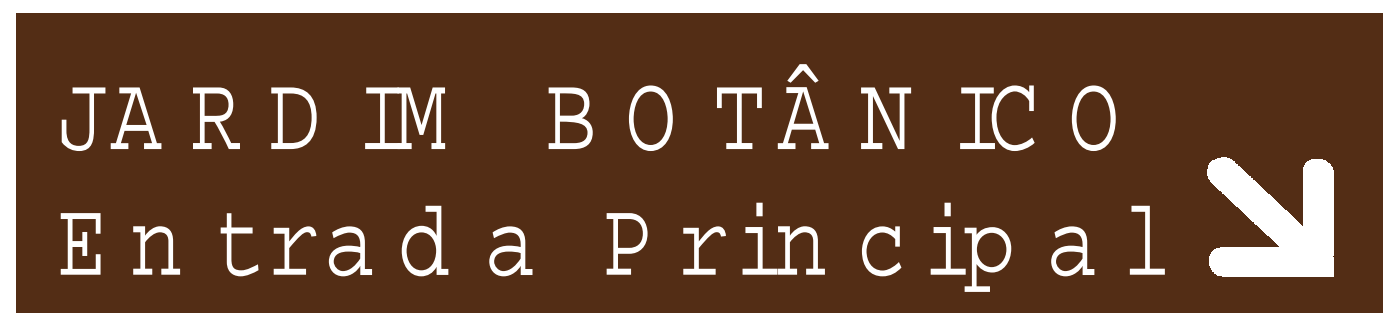

Modelo 02

O JBB pode fazer uma solicitação ao DNER ou DETRAN para que implantem essas placas nestas vias.

Na figura 02 é observado o elemento feito de lâminas de madeira com letras-caixa brancas. Para a identificação do JBB, a placa ideal deve ter como mensagens o símbolo da unidade e seu nome. O fundo deve ser de cor areia, as letras e fio de separação de mensagens pretos e símbolo da unidade, a cores. O alfabeto é em negrito e caixa alta. Optima ou Zapt Humanist 601 será adotado em todos os modelos propostos dentro e fora do local.

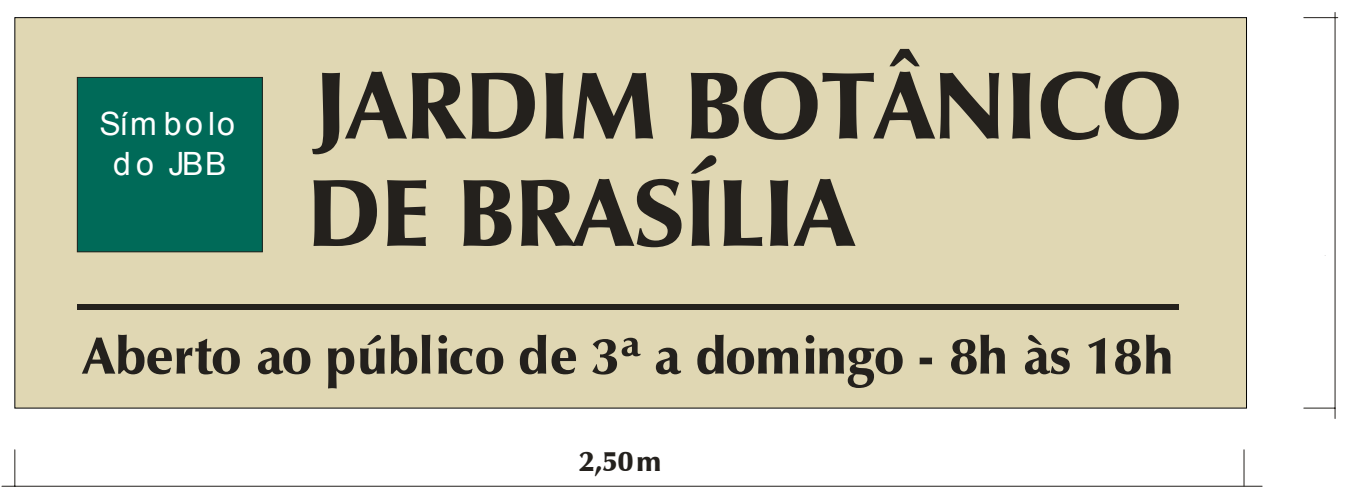

\section{Modelo 03}

A figura 03 apresenta a placa da entrada do JBB que é a placa de acesso, com ilustrações, horários de funcionamento e restrições de acesso. $O$ 
alfabeto deve ser em caixa alta e baixa e tem o símbolo do JBB, seu fundo tem cor branca e letras e fio de separação pretos. Este elemento está de acordo com as recomendações do manual utilizado.

$\mathrm{Na}$ figura 06 pode ser observado o exemplo de placas que são largamente usadas em toda a área de visitação. Estas placas são de indicação, de madeira com as letras em caixa alta entalhadas e pintadas de branco, mas devem ser usadas letras em caixa alta e baixa e com no máximo quatro mensagens. O ideal é que seja usada só uma lâmina para todas as mensagens e estas separadas por uma tarja, como o elemento da figura 12. Mas poderá ser usada uma lâmina em cada mensagem, totalizando no máximo quatro lâminas. Com altura média de $70 \mathrm{~cm}$, o elemento é baixo e pode ficar fora do campo de visão do visitante, devendo ser de pelo menos $1 \mathrm{~m}$. Segue abaixo um modelo proposto para cada uma das quatro opções.

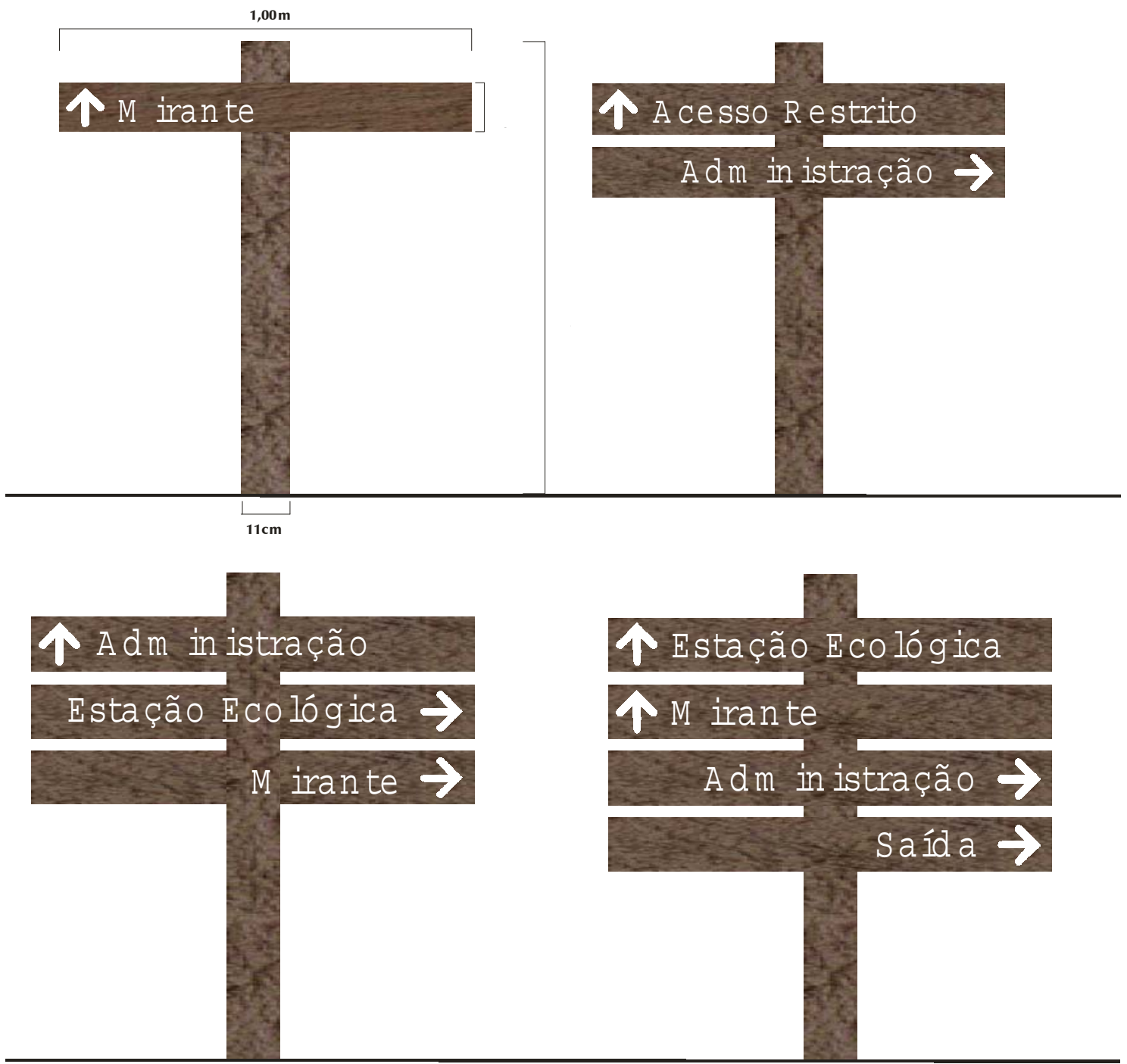

Modelo 04

O signo direcional deve estar próximo à mensagem para que o usuário possa associá-los imediatamente, na primeira leitura. Se estiverem distantes um do outro, a compreensão pode ser mais demorada. 
O elemento 12B observado na figura 15 está bem preservado, mas é feito de metal e está inserido em uma área onde os elementos de madeira com letras brancas são predominantes, portanto deve ser substituída pelo apresentado acima, com a mensagem em caixa alta e baixa.

Além destes tipos mais comuns, são encontrados ainda na área que dá acesso à Administração, elementos como o da figura 17 que é uma placa de madeira pintada de branco e letras amarelas, em forma de seta e a figura 11, que é um banner de plástico e fundo branco com letras pretas, seta vermelha e mais três símbolos diferentes de patrocinadores. Essas características não estão de acordo com qualquer especificação de qualquer manual especializado na área de sinalização gráfica.

A proposta é que sejam retirados estes elementos e como suas mensagens são de indicação, ou de direção, o proposto é o modelo 4 ou o da figura 12, utilizado na Estação Ecológica e na tabela 02 são os elementos P30 e P31, respectivamente.

Na própria área da Administração, os elementos 29A e 34A são de madeira pintada de verde com letras brancas e também não estão de acordo com qualquer norma especializada. Já os elementos 93B e 32B são de metal com fundo verde e letras brancas em caixa alta.

Como são de identificação do local, devem ser substituídos pelo modelo abaixo, com fundo azul ou marrom, letras brancas, em negrito e caixa alta e baixa.

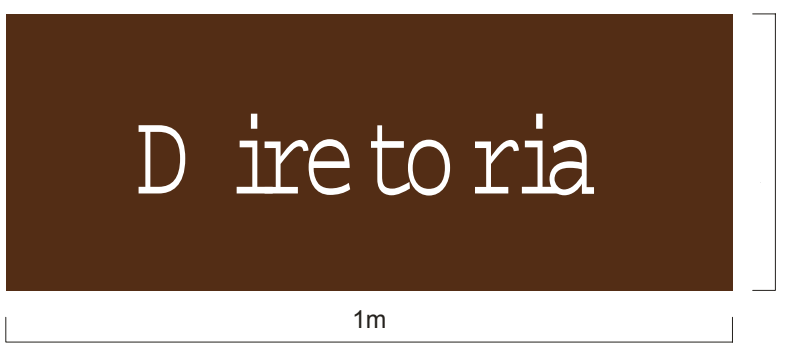

\section{Modelo 05}

Devem ser retirados também os elementos 65F (figura 22), 41B (figura 23), 52B (figura 24), e $92 \mathrm{~F}$ que foram depredados, e os apresentados nas figuras 21 e 25 que estão desgastados pela ação do tempo.

Nos casos dos elementos 65F, 92F e figuras 21 e 25, pode ser feita a substituição por placas iguais, porém com todas as letras que compõem 0 texto.

Para os elementos 41B e 52B, como são de identificação de divisas deve ser utilizado o mesmo modelo que a figura 10 representa, com fundo areia, letras pretas em caixa alta para o título e alta e baixa para uma advertência e assinatura do JBB. Como esta não é Unidade de Conservação Federal, admite-se a assinatura do Governo do Distrito Federal (GDF), de acordo com o indicado no manual. 
Na figura 07 foi utilizado o mapa-índice da área de visitação do JBB, com as cores recomendadas, porém com caixa alta no título em vez de alta e baixa. O fundo é branco e as letras pretas, também de acordo com as recomendações. Deveria ser incluído no mapa a indicação "Você está aqui" para que o visitante saiba sua posição.

A camada de verniz deste mesmo elemento está descascando, também causando desconforto visual ao visitante, apesar de não interferir na legibilidade do texto. Isso diminui a proteção das camadas inferiores de tinta que podem vir a estragar posteriormente e o custo para refazê-las será maior do que simplesmente retocar o verniz.

Já a figura 08 traz pequenas placas de metal, fundo azul, letras brancas com o símbolo do patrocinador e traz os nomes popular e científico das espécies encontradas na área. Não têm a origem por se tratar de espécies nativas e o número de catalogação só se for necessário. Em relação às mensagens, estes elementos estão corretos, devendo ser incluído mais um item, por exemplo, alguma peculiaridade da espécie.

Para esse tipo de sinalização que é a identificação de espécies vegetais, a cor do fundo deve ser areia e das letras marrom, como podemos observar no modelo abaixo.

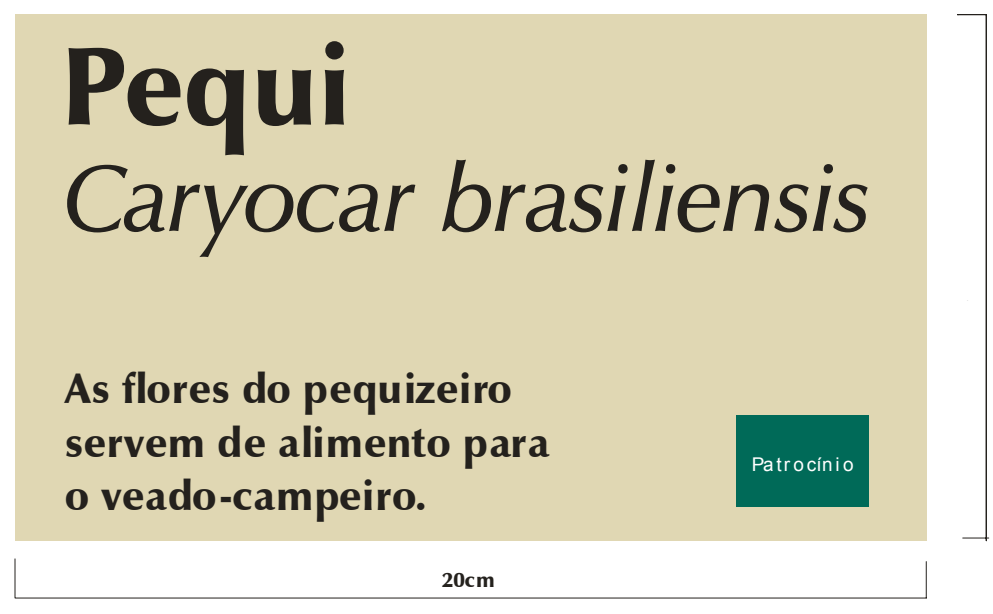

\section{Modelo 06}

A figura 09 mostra um elemento com fundo de cor branca e letras em caixa alta de cor verde, de sigla que não é explicada. Pode ser substituído por uma placa seguindo o modelo 05 , na tabela 02 como elemento P27, com a significação da sigla, pois esta representa a indicação do local onde é a unidade do Corpo de Bombeiros, importante informação tanto para visitantes como para os funcionários.

$\mathrm{Na}$ área do estudo foram utilizados basicamente dois tipos de material, para a confecção da maioria dos elementos: a madeira e o metal. É uma boa escolha, pois são materiais de custo moderado e boa resistência, embora o ideal é que se use somente um tipo.

Essa recomendação é feita porque quanto maior a variedade de material, maior a necessidade de diferentes mãos de obra especializadas para 
a fabricação, implantação e substituição ou conserto, por este motivo, no JBB não se deve incluir outro tipo de material.

Estão ainda sendo fixadas as placas do Modelo Filogenético. A placa da figura 18 é feita de metal é um sinal de aviso para alertar as condições de uso da área, com fundo verde, letras brancas, o símbolo do Ministério do Meio Ambiente e a mensagem em dois idiomas. O modelo recomendado para esse tipo de sinal é com o fundo branco, a mensagem com letras pretas, em negrito e caixa alta e baixa para títulos e demi em caixa alta e baixa para os textos complementares.

O elemento da figura 19 apresenta o mapa índice da área do Modelo Filogenético com fundo branco e mensagens em cor azul, com o símbolo do Ministério do Meio Ambiente. O sinal deve seguir o mesmo modelo da figura 17.

O sinal gráfico deve servir também para a identificação de algum local, serviço ou indicar a direção que o visitante deve tomar. Os elementos da sinalização devem estar em posições de fácil localização, permitindo o usuário fazer alguma escolha de roteiro e nos mapas já dentro da área de visitação, podem ser observados diversos pontos que são cruzamentos que não possuem qualquer tipo de sinalização.

Em alguns casos, como pode ser visto na figura 27 , há vegetação cobrindo parte do elemento. É importante que se faça a manutenção periódica da poda nestes locais para que isso não atrapalhe ou impeça a visão do usuário. Neste caso existe o agravante de a placa ser de madeira e estar atrás de uma árvore de mesma cor. Este elemento dificilmente será notado pelo visitante.

$\mathrm{Na}$ figura 27, este elemento se encontra em um entroncamento de 3 trilhas que têm o fluxo em todos os sentidos, mas a mensagem está voltada somente para um lado, impedindo sua leitura por quem transita pelas outras duas trilhas.

Mesmo com boa resistência, assim como qualquer outro que for usado, o metal e a madeira estão sujeitos à ação do tempo e do vandalismo. Na figura 20 , percebe-se a letra "J" retorcida, justamente na placa da entrada principal, o que causa má impressão ao visitante. Nas figuras 23 e 24, os elementos estão pichados e nas figuras 21 e 25 , os elementos estão desgastados o que demonstra falta de manutenção.

E há os casos em que a legibilidade do texto está comprometida pela falta das letras, como na figura 22.

Um sistema de sinalização bem implantado deve trazer ao visitante bemestar, tranqüilidade, conforto e segurança, aumentando a simpatia em relação ao local e sua administração e reduzindo os riscos de acidentes pela própria melhoria da circulação em sua área.

Em parte do trajeto, que pode ser feito a pé ou de carro a partir da portaria há placas com mensagens e desenhos de fauna e flora, como na figura 
04. É possível a leitura da mensagem, pois a via é de velocidade máxima de 40 $\mathrm{km} / \mathrm{h}$, mas os desenhos e suas legendas são pequenos demais para serem observados por motoristas.

É importante citar novamente o elemento da figura 12, uma placa de metal de fundo marrom, signos direcionais e letras brancas, que não está na área de visitação. $\mathrm{Na}$ área da Estação Ecológica, todas as placas seguem padrão estabelecido em projeto que segue o manual como base, mantendo a unidade visual. Alguns poucos elementos começaram a sofrer com a ação do tempo, mas em todos os cruzamentos há algum tipo de indicação, impedindo que o usuário se perca.

Para um sistema gráfico eficiente, é fundamental que se faça o planejamento para o projeto de sinalização visual determinando a área a ser trabalhada, como será trabalhada, quais serão as prioridades, quais modelos serão usados e onde serão instalados. 
TABELA 02 - Sinalização proposta para o JBB

\begin{tabular}{|c|c|c|c|c|}
\hline $\mathbf{N}^{\circ}$ & Código & Tipo de Sinalização & Mensagem & Mapa \\
\hline 1 & $\mathrm{P}$ & Indicação & $\begin{array}{l}\text { Centro de Visitantes/ Saída/ } \\
\text { Mirante }\end{array}$ & 01 \\
\hline 2 & $\mathrm{P}$ & Indicação & Mirante/ Centro de Visitantes & 01 \\
\hline 3 & $\mathrm{P}$ & Indicação & Saída & 01 \\
\hline 4 & $P$ & Indicação & $\begin{array}{l}\text { Centro de Visitantes/ Mirante/ } \\
\text { Saída }\end{array}$ & 01 \\
\hline 5 & $\mathrm{P}$ & Indicação & $\begin{array}{l}\text { Alameda das Nações/ Centro de } \\
\text { Visitantes/ Saída }\end{array}$ & 01 \\
\hline 6 & $\mathrm{P}$ & Indicação & Mirante & 01 \\
\hline 7 & $P$ & Indicação & $\begin{array}{l}\text { Centro de Visitantes/Mirante/ } \\
\text { Saída }\end{array}$ & 01 \\
\hline 8 & $\mathrm{P}$ & Indicação & Mirante/ Estação Ecológica & 01 \\
\hline 9 & $P$ & Indicação & Estação Ecológica/ Mirante & 01 \\
\hline 10 & $P$ & Indicação & $\begin{array}{l}\text { Mirante/ Administração/ Centro } \\
\text { de Visitantes }\end{array}$ & 02 \\
\hline 11 & $\mathrm{P}$ & Indicação & Retorno & 02 \\
\hline 12 & $P$ & Indicação & $\begin{array}{l}\text { Estação Ecológica/ } \\
\text { Administração/ Centro de } \\
\text { Visitantes }\end{array}$ & 02 \\
\hline 13 & $\mathrm{P}$ & Indicação & Mirante & 02 \\
\hline 14 & $\mathrm{P}$ & $\begin{array}{l}\text { Identificação e } \\
\text { regulamentação }\end{array}$ & $\begin{array}{l}\text { Estação Ecológica/ Acesso } \\
\text { Restrito }\end{array}$ & 02 \\
\hline 15 & $\mathrm{P}$ & Indicação & $\begin{array}{l}\text { Administração/ Estação } \\
\text { Ecológica }\end{array}$ & 02 \\
\hline 16 & $\mathrm{P}$ & Indicação & Mirante/ Estação Ecológica & 02 \\
\hline 17 & $\mathrm{P}$ & $\begin{array}{l}\text { Indicação e } \\
\text { regulamentação }\end{array}$ & Área Restrita/ Administração & 02 \\
\hline 18 & $\mathrm{P}$ & Indicação & $\begin{array}{l}\text { Estação Ecológica/ Mirante/ } \\
\text { Administração/ Centro de } \\
\text { Visitantes }\end{array}$ & 02 \\
\hline 19 & $P$ & Indicação & $\begin{array}{l}\text { Administração/ Estação } \\
\text { Ecológica/ Mirante }\end{array}$ & 02 \\
\hline 20 & $\mathrm{P}$ & Indicação & Administração & 02 \\
\hline 21 & $P$ & & $\begin{array}{l}\text { Estação Ecológica/ Mirante/ } \\
\text { Administração }\end{array}$ & 02 \\
\hline 22 & $\mathrm{P}$ & Indicação & Estação Ecológica & 02 \\
\hline 23 & $\mathrm{P}$ & Indicação & $\begin{array}{l}\text { Administração/ Centro de } \\
\text { Visitantes }\end{array}$ & 02 \\
\hline 24 & $\mathrm{P}$ & $\begin{array}{l}\text { Indicação e } \\
\text { regulamentação }\end{array}$ & $\begin{array}{l}\text { Centro de Visitantes/ Acesso } \\
\text { Restrito }\end{array}$ & 02 \\
\hline 25 & $\mathrm{P}$ & $\begin{array}{l}\text { Indicação e } \\
\text { regulamentação }\end{array}$ & Administração/ Acesso Restrito & 02 \\
\hline 26 & $P$ & Indicação & Trilha Ecológica & $\begin{array}{l}\text { Placa de } \\
\text { substitui- } \\
\text { ção }\end{array}$ \\
\hline 27 & $\mathrm{P}$ & Indicação & $\begin{array}{l}\text { Corpo de Bombeiros Militar do } \\
\text { DF HID nº } 03\end{array}$ & $\begin{array}{l}\text { Placa de } \\
\text { substitui- } \\
\text { ção }\end{array}$ \\
\hline 28 & $\mathrm{P}$ & Orientação & $\begin{array}{l}\text { Jardim Botânico de Brasília/ } \\
\text { Entrada a } 50 \mathrm{~m}\end{array}$ & $\begin{array}{l}\text { Na via DF- } \\
035\end{array}$ \\
\hline 29 & P & Orientação & $\begin{array}{l}\text { Jardim Botânico de Brasília/ } \\
\text { Entrada a } 100 \mathrm{~m}\end{array}$ & $\begin{array}{l}\text { Na via DF- } \\
035\end{array}$ \\
\hline
\end{tabular}


TABELA 02 - Sinalização proposta para o JBB

\begin{tabular}{|l|l|l|l|l|}
\hline \multicolumn{1}{|c|}{$\mathbf{N}^{0}$} & Código & Tipo de Sinalização & \multicolumn{1}{|c|}{ Mensagem } & Mapa \\
\hline 30 & $\mathrm{P}$ & Indicação & Saída & $\begin{array}{l}\text { Placa de } \\
\text { substitui- } \\
\text { ção }\end{array}$ \\
\hline 31 & $\mathrm{P}$ & Indicação & Diretoria & $\begin{array}{l}\text { Placa de } \\
\text { substitui- } \\
\text { ção }\end{array}$ \\
\hline 32 & $\mathrm{P}$ & Indicação & $\begin{array}{l}\text { Centro de Visitantes/ Estação } \\
\text { Ecológica }\end{array}$ & 02 \\
\hline 33 & $\mathrm{P}$ & Indicação & Mirante/ Estação Ecológica & 02 \\
\hline 34 & $\mathrm{P}$ & Indicação & Saída/ Mirante & 01 \\
\hline 35 & $\mathrm{P}$ & Indicação & Saída/ Centro de Visitantes & 01 \\
\hline 36 & $\mathrm{P}$ & Indicação & Saída/ Mirante & 01 \\
\hline 37 & $\mathrm{P}$ & Indicação & Saída/ Centro de Visitantes & 01 \\
\hline
\end{tabular}




\section{CONSIDERAÇÕES FINAIS}

Constatou-se neste estudo, que a sinalização atual do Jardim Botânico apesar de utilizar poucos tipos de material, não consegue a uniformidade visual por causa da grande variedade de cores, alfabetos, tamanhos e formas dos elementos. Esta uniformidade é importante para o aspecto estético do local, principalmente por esta ser área natural e de preservação.

Nos casos da sinalização externa ao JBB, é necessário que seja solicitada ao DNER ou DETRAN a implantação de indicação e orientação do local.

É necessário que se amenize essa disparidade reduzindo os diferentes tipos de elementos, utilizando modelos para caracterização de temas.

No JBB, está havendo pouca manutenção por parte da administração, pois foram encontrados diversos elementos avariados.

Verificada a falta de elementos de indicação ou orientação em pontos de cruzamentos e interseções, recomenda-se que eles sejam implantados nestes lugares para assegurar ao visitante o conforto e segurança dentro das dependências do JBB.

A falta de compatibilização dos diversos estudos realizados para o sistema implantado é a causa destas dificuldades apresentadas na área estuda, apesar de já serem encontradas obras especializadas em sinalização de áreas naturais e de ter já sido apresentado um projeto de complementação em 1998.

Em resumo, para que os visitantes do Jardim Botânico de Brasília possam ter visita agradável e segura e para que seja alcançado o objetivo da unidade de levar informações e lazer garantindo a preservação, a sinalização é um instrumento determinante.

A substituição dos elementos existentes do JBB, não deve ser feita necessariamente de uma só vez. As placas podem ser trocadas aos poucos, de acordo com a disponibilidade de recursos da administração. O importante é que sejam feitas as mudanças para que o parque possa fazer parte das unidades que atendem às recomendações sugeridas pelo IBAMA. 


\section{GLOSSÁRIO}

Acabamento: remate, conclusão, última demão que se dá a uma obra.

Banner: elemento feito de material flexível e maleável, com duas das extremidades afixadas em um suporte. Normalmente utilizado em propaganda.

Conservação in situ: conservação de ecossistemas e habitats naturais e a manutenção e recuperação de populações viáveis de espécies em seus meios naturais e, no caso de espécies domesticadas ou cultivadas, nos meios onde tenham desenvolvido suas propriedades características.

Pictograma: representação gráfica de funções, atividades e serviços existentes na área. São utilizados como comunicação universal e imediata, de fácil percepção à distância e de alta legibilidade.

Plano de Manejo: documento técnico mediante o qual, com fundamento nos objetivos gerais de uma unidade de conservação, se estabelece o seu zoneamento e as normas que devem presidir o uso da área e o manejo dos recursos naturais, inclusive a implantação das estruturas físicas necessárias à gestão da unidade.

Preservação: conjunto de métodos, procedimentos e políticas que visem a proteção a longo prazo das espécies, habitats e ecossistemas, além da manutenção dos processos ecológicos, prevenindo a simplificação dos sistemas naturais.

Signo direcional: sinal indicador da direção a seguir.

Símbolo: elemento gráfico ou objeto que representa ou indica de forma convencional um elemento importante para o esclarecimento de alguma coisa.

Sistema de Sinalização Visual ou gráfica: é constituído de um conjunto de mensagens visuais organizadas segundo uma linguagem gráfica e aplicado num conjunto de suportes. Essas mensagens visuais estão programadas para fornecer informações sobre funções e atividades desenvolvidas no espaço edificado, ou fora dele, obedecidos os códigos estabelecidos para a transmissão das mensagens.

Unidade de Conservação: espaço territorial e seus recursos ambientais, incluindo as águas jurisdicionais, com características naturais relevantes, legalmente instituído pelo Poder Público, com objetivos de conservação e limites definidos, sob regime de administração, ao qual se aplicam garantias adequadas de proteção. 


\section{REFERÊNCIAS BIBLIOGRÁFICAS}

BEZERRA MARTINS. Leitura Semiótica Aplicada al Conocimiento del Espacio Urbano: Analisis de la Señalizacion Turistico-Cultural como Representacion Grafica en Sitios Historicos. Tese de Doutorado. Barcelona, Universitat Politecnica de Catalunya, 1996, 327p.

BRASIL. Decreto no 9.985, de 18 de julho de 2000. Regulamenta o art. 225, § $1_{-}^{\circ}$, incisos I, II, III e VII da Constituição Federal, institui o Sistema Nacional de Unidades de Conservação da Natureza e dá outras providências. Diário Oficial (da República Federativa do Brasil), Brasília, 19 de julho de 2000.

DAVIDOFF, L. L. Introdução à Psicologia. São Paulo: Makron Books do Brasil Ed. Ltda., 1983.

FARINA, M. Psicodinâmica das cores em Comunicação. São Paulo: Ed. Edgard Blücher Ltda., 1982.

FOLLIS, J., HAMMER, D. Architectural Signing and Graphics. New York: Wihtney Library of Design, 1979.

MINISTÉRIO DO MEIO AMBIENTE. ECOTURISMO: Visitar para conservar e desenvolver a Amazônia. Brasília, 2002.

MITZI SIMS. Gráfica del Entorno: Signos, Senales y Rótulos. Técnicas y Materiales. Barcelona: Ed. Gustavo Gili, S. A., 1991.

MORAIS BARBOSA, A. D., TRONCOSO, C. R. Orientação para Sinalização Visual de Unidades de Conservação Federais. Brasília, 1997.

MORGAN, C. T. Introdução à Psicologia. São Paulo: Mc Graw-Hill, 1977.

Sign System Specifications. Denver Service Center, 1975

UNITED STATES DEPARTMENT OF THE INTERIOR. National Park Service. Manual para la Capacitacion del Personal de Areas Protegidas. Washington: Alan Moore, 1993.

UNIVERSAL, Delta. Enciclopédia. Rio de Janeiro: Delta S.A., 1988, volume 4. 